Boletim IG. Instituto de Geociências, USP, V. 9 : 153-201, 1978

\title{
ON THE ANATOMY OF WOOD SHOWING AFFINITIES WITH THE GENUS VERTEBRARIA ROYLE, FROM THE IRATI FORMATION, STATE OF SĀO PAULO, BRAZIL**
}

\author{
DIANA MUSSA \\ Departamento de Paleontologia e Estratigrafia \\ $\mathrm{e}$ \\ Comissão Nacional de Energia Nuclear - CNEN*
}

\begin{abstract}
Results of research on permineralized wood samples from the Irati Formation (middle to upper Permian) in the State of São Paulo, Brazil add to our understanding of several questionable problems concerning samples showing affinities with the vertebrarian types of axes. A new xylic structural plan including even roots and stems would have been characterized throughout Gondwanaland from post-glacial time through the Late Permian. Until now a number of samples had been described as a single taxonomic unit under the designation of Vertebraria indica Royle 1939. Presumably this taxon does not include only a single generic group, but rather it represents a complex of forms distributed throughout Gondwanaland that are grouped together on the basis of important and similar features, such as: 1) wedge-shaped stelic configuration resembling that of the vertebrarian stelic plan; 2) wavy grouwth rings and asymmetric growth of the vascular cilynder resulting from the cambial activity of ray cells and parenchyma cells in the rings; 3) a frequent and peculiar pitting arrangement on the radial walls of the tracheids which now appears to be also a common feature among glossopteridean shoots and vertebrarian axes. It was possible to identify some samples as independent and definite genera on the basis of their well-preserved leaf and root traces, their nodal structures and also their very characteristic manner of issuing adventitious branches. Eventhough they are not classified in the genus Vertebraria, they are closely comparable in many aspects to axes of this genus. A discussion is presented here of the genus Vertebraria and it is concluded that the related genus Tordoxylon Kräusel 1956 is a valid taxon that can be distinguished within the vertebrarian complex on the basis of its characteristic xylic plan. Some problems concerning taxonomic names are also discussed. A preliminary account of the paleoecological significance of these anatomical structures is presented in view of their rapid rise and extinction during geologic time.
\end{abstract}

\footnotetext{
* Bolsista do Conselho Nacional de Desenvolvimento Científico e Tecnológico - CNPq.

** Contribution to the Project PIGG 42 UPPER Palebzoic of South America.
} 


\section{RESUMO}

Os resultados das pesquisas em lignispécimes permineralizados da formação Irati (Permiano médio a superior), Estado de São Paulo, Brasil, fornecem novos subsídios para o entendimento de diversas questões ainda pendentes, quanto às estruturas xílicas anatomicamente afins aos órgãos vasculares do tipo "Vertebraria". Plano xílico novo, que incluia raízes e caules deveria ter existido em todo o Gondwana, a partir do tempos pós glaciais, ao final do Permiano. Até o presente, bom número de amostras foi descrito sob unidade taxonômica, única, designada Vertebraria indica Royle 1939. Presumivelmente esse taxon não inclui, somente, um gênero, mas, preferencialmente, representa um complexo de gêneros distribuidos através do Gondwana. Os mesmos podem ser grupados com base em importantes características, bastante semelhantes, como: 1) configuração estélica, em cunhas, assemelhando-se ao plano estélico de "Vertebraria"; 2) anéis de crescimento ondulantes associados a crescimento assimétrico do cilindro vascular, como resultado da atividade cambial das células dos raios e das células de parênquima presentes nos anéis; 3) arranjo das pontuações, sobre as paredes radiais dos traqueídeos, bastante peculiar; esse arranjo parece ter sido comum, tanto em ápices caulinares de glossopterídeas, quanto em órgãos vasculares designados como "Vertebraria".

$\mathrm{Na}$ presente pesquisa foi possível identificar gêneros independentes e definidos com base em estruturas bem preservadas, relativas a traços foliares e a traços de raízes adventícias; tornou-se possível a identificação de estrutura nodal típica e um modo bastante característico de emitir ramos, em algumas das amostras. Embora todas as formas, aqui estudadas, não tenham sido classificadas no gênero Vertebraria, são compatíveis em muitos aspectos ao referido gênero. Portanto, oferecemos uma discussão a respeito do complexo Vertebraria e concluimos que Tordoxylon Kräusel 1956 é um gênero válido, o qual pode ser reconhecido em meio ao referido complexo, levando-se em consideração o seu plano xílico, muito peculiar. Alguns problemas relativos à nomenclatura dos espécimes são também discutidos no presente trabalho. Apreciação preliminar, sobre o significado paleoecológico, das estruturas anatômicas, foi aqui situada, tendo em vista o rápido surgimento e desaparecimento dessas formas gondwanicas.

This paper was presented at the 29 ? Congresso Brasileiro de Geologia (October 1976, Belo Horizonte, Minas Gerais, Brasil). Prof. Dr. A. C. Rocha-Campos (Instituto de Geociências, Universidade de São Paulo) very kindly took an early copy to India (occasion of the IV Gondwana Symposium) in order to show it to the paleobotanists Dr. K. R. Surange and Dr. H. K. Maheshwari (of the Birbal Sahni Institute, Lucknow) for criticism. When Dr. A. C. Rocha-Campos could not go to Lucknow Dr. O. Rösler graciously took it to them. I am deeply grateful to all these people. And also to Dr. T. R. Fairshild (Visiting-Professor, IG-USP) for the considerable time he spent reviewing the English-text and to Drs. Bertha L. de Morretes and Nanuza L. Meneses for many interesting discussions.
To Dr. A. C. Rocha-Campos I dedicate one species as my homage and thanks for his intelectual help in many ocasions.

\section{Sample Localities:}

Over the years fossil wood samples have been collected from several dolomite quarries in the Irati Formation of the State of São Paulo (Fig. 1-a). Many of them have been described previously by Maniero (1946-1948)* and Kräusel \& Dolianiti (1958) and included in the genera Parataxopytis, Solenopytis, Polysolenoxylon etc.

The Irati Formation is the basal unit of the Passa Dois Group (Permian) of the

* in Kräusel et. al., 1958 


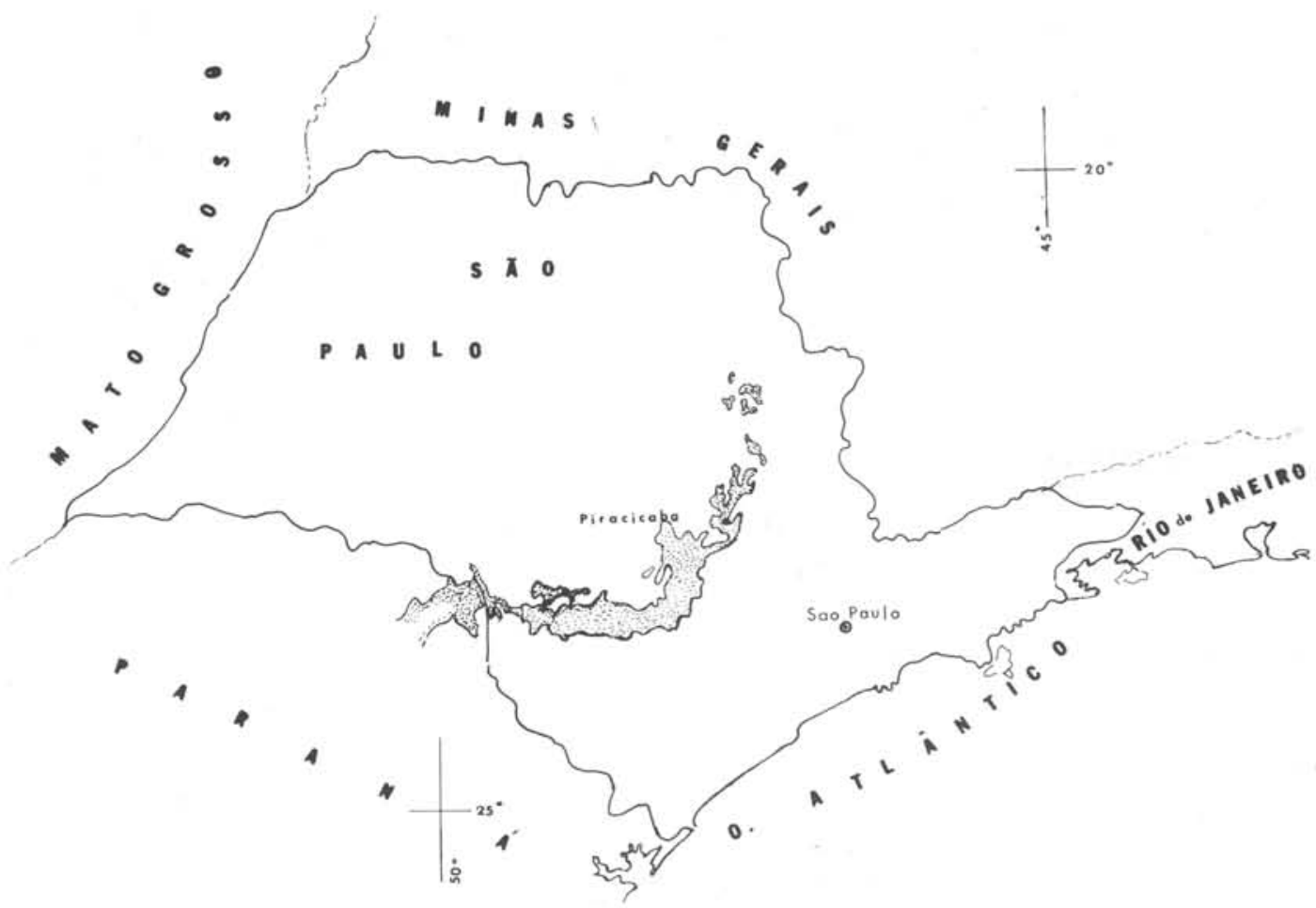

FIG. 1-a

Distribution of Passa Dois Group (Irati Formation included) in the State of Sấo Paulo (Geological map of the State of São Paulo, 1963).

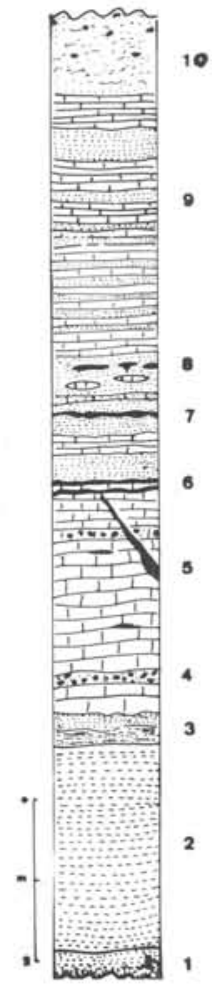

FIG. 1-b

Geologic section of Vitti Quarry laccording to Amaral, 1971).

1. Black pyrobituminous shale with black syngenetic nodules of chert.

2. Argillaceous siltstone rich in siliceous sponge spicules ("lage azul").

3. Milimetric corrugated layers of shale ("lage fria").

4. Intraformational breccia.

5. Massive dolostone with rare nodules, thin layers and veins of chert.

6. Chert.

7. Shale with nodular chert layers.

8. Shale with chert and dolostone lenses.

9. Rhythmic alternation of dolostone and shale (up to $6 \mathrm{~m}$ of thickness).

10. Soil with chert nodules.
Paraná Basin of SE Brazil. It comprises dolostone, bituminous shales and chert interbedded in a siltic body (Fúlfaro, 1971). At the present time the Irati Formation is no longer considered as representing a single depositional phase within the Permian, but rather as a set of associated facies in which depositional conditions varied from more to less reducing environments (Mendes, et al., 1966).

A columnar section of the Vitti Quarry (former Maluf Quarry) presented by Amaral (1971) is included in here (Fig. 1-b) as a typical section for the various quarries in the Piracicaba region. Mezzalira (1971) reports that many fossil wood samples were collected from the basal dolostone portion of this formation, but presentely many samples were also obtained from the upper part of the unit, made up of interbed dolostoic and shale beds (Fig. 1-b).

The wood samples described in this paper come from two dolomite quarries, the first locally called Vitti Quarry is located 
$18 \mathrm{~km}$ north of Piracicaba and approximately $500 \mathrm{~m} \mathrm{~W}$ of the Washington Luis state road; the second known as Moura Quarry is about few kilometers of the first.

Results of palynologycal analysis (Daemon \& Quadros, 1970) indicate the dominance of bisaccate forms with a large amount of bisaccate striatiti in the Irati microflora. This has been interpreted as indicating a Late Permian (Kazanian), age

The microflora also evidenced a change from an initial mild passing to warm and dry climate during the deposition of the Formation, which also included several local humid (swamp) areas.

The Irati Formation is considered a correlative sedimentary sequence of the White Band Formation, which overlyes the Dwyka Series in South and South-West Africa.

\section{ACCOUNT ON PREVIOUS RESEARCH ON VERTEBRARIAN TYPES OF AXES}

As an introduction, an account of previous research on vertebrarian types of axes is here presented because of the inclusion of the genus Tordoxylon Kräusel 1956 as a synonym (Schopf, 1965) of the genus Vertebraria Royle 1939.*

Several samples collected, from the Irati Formation, in the State of São Paulo resemble the anatomical set of Tordoxylon, but they are differentiated in many anatomical aspects concerning the genus Vertebraria; the following discussion of this point will stablish that Tordoxylon is a valid generic name.

With regard to the genus Vertebraria Royle 1939 there are still many questions to be answered concerning the characterization of the xylem plan of the axes included in this Gondwanic genus. The first and most complex of these is: does this taxon refer to a single genus dispersed throughout Gondwanaland, or does it include several independent genera brought together by their common stelic-plan? In other words, does a vertebrarian xylic-plan imply only a single genus or is it a complex? With respect to the former possibility a new aspect arises: how valid is it to assign a single name, ever since its first description to diversely described forms? The first known specimens were described merely on the basis of their external morphology and later descriptions were based on the anatomy data of the xylem. The first authors assigned the name Vertebraria to impressions and compressions of the plant axis, and later authors used the name for petrified wood, without mentioning the external morphological features upon which this genus had formerly been based.

Vertebraria was a taxonomic name stablished without and elaborated generic diagnosis by Royle. His descriptions and detailed illustrations stressed the assumption of Vertebraria as a genus, described from compressions and impressions of several peculiar axes of a plant; these axes were formed by sucessive rectangular blocks separated by longitudinal and transversal furrows resembling a set of vertebrae, hence the name. Transversely the fossils showed an almost circular crosssection separated into wedge-shaped sections. Since the earlier descriptions to the present, their nature whether a root or a rhizome as well as their systematic position has been much discussed. But whether these axes were roots or stems is an essential question to clarify the interpretations as to environmental conditions during the life-time of the plant: stems more than roots concentrate a number of features favorable for paleoecological interpretations.

Three progressive approaches characterize research on vertebrarian types of axes (Table 1). In the first, results were based on external morphological data; in the second approach authors combined the external morphological data with preliminary anatomical data and later they emphasized only the anatomical features. A third approach was introduced by authors who attempted to synthesize all results up to the present.

The following comments refer to the works concerned to the first approach: Mc Coy (1847) in describing Australian specimens supposed the axes to be the verticils of a

* Fide Surange \& Maheshwari, 1962 
Sphenophyte, but (apud Arber, 1905) he admitted that they might represent glossopteridean rhizomes. Bunbury (1861) working on samples from Nagpur, India, showed that the axes were cylindrical organs with a massive central column. He considered his axes to be roots, but related them to the genus Phyllotheca. Feistmantel $(1881,1886)$ studied many specimeris from several Indian localities, covering almost all of the Permian section in that country. He conceived the vertebrarian axes to be rhizomes but still he placed them among the Sphenophyta. Zeiller (1896) was the first to clearly relate the axes to the Glossopteridales, identifying compressions of glossopteridean leaves in apparent organic connection with an axis. $\mathrm{He}$ emphasized a rhizomatous nature for his samples and was the first author to claim a liversity in the external aspects of several axes, pointing out structures interpreted as leaf scars. Oldham (1897) confirmed Bunbury's ideas in several asrects. He recognized a massive central core bound to an external vascular cylinder by means of radial arms or wedges. He pointed out the occurrence of aliform gaps between those arms. By means of a structural reconstruction, he showed massive transversal septa in the gaps at different levels binding each pair of arms. Oldham's study was restricted to a few compressed samples, but he produced an admirable interpretation in the structural sketch of Vertebraria, to which many modern anatomical interpretations would refer in the future (Text - Fig. 1-c).

Walton \& Wilson (1932) initiated a new approach in the research on vertebrarian types of axes. They studied a Rhodesian sample describing for the first time micronatomical features from carbonized parts of the plant axes; their thin sections were longitudinal, thus they showed the anatomical features of the secondary xylem. Their main conclusion was the assignement of Vertebraria to the Spermatophyta (Pteridospermae or Gymnospermae, still under discussion). They commented on the scarcity of evidence as to wether Vertebraria was a glossopteridean stem; they included an illustration of a glossopteridean axis with leaves connected to it, but the axis was quite unlike Vertebraria. Sen $(1955,1958)$ studied Indian samples and Pant (1956) worked on a sample from Mhukuru Coalfield, Tanganika. Their results added to the work of Walton \& Wilson. Pant (1956) commented on the occurrence of spiral tracheids and thin-walled parenchyma-like cells in the wood. All of these authors in describing their specimens assigned the classical designation Vertebraria indica Royle 1839 to them, since their results combined anatomical data with those of the external morphology.

Kräusel (1956) studied several silicified pieces of wood from South Africa, and he conceived them be similar to lianas. In his work he introduced a description of a small sample, Tordoxylon steinspruitense, which had a completely new structure, whose transverse section was similar to a polyarch root, but the microanatomical features concerned to a stem. The author did not compare his sample with those of Vertebraria, because it was neither an impression nor a compression, but rather a silicified petrifaction withouth the morphological features upon which Vertebraria had been founded. He showed an asymmetry in the growth of the vascular cylinder which concluded was the result of the cambial activity of parenchyma cells in the growth tings. Some asymmetry had previously been reported in compressed vertebrarian axes as seen in Walton \& Wilson's work (cf. p. 205) but had been understood as a result of compression..

Surange \& Maheshwari (1962) presented the results of their work on samples from the Raniganj Coalfield in India. They distinguished two species of Vertebraria: $V$. raniganjensis and $V$. myelonis. The first was differentiated from $V$. indica by its higher rays and the second by its morphological indication of a pith. The main result of this work was that a glossopteridean axis having connected leaves had anatomical features like those of $V$. raniganjensis. This discovery was to permit later correlations between several petrified stems and glossopteridean plants simply on the basis of their anatomical features.

Maithy (1965) studied a new collection from the Karhabari Coalfields (Giridih). $\mathrm{He}$ concluded that his Vertebraria samples were similar to those described by others as $V$. indica. However, he chose a new designation 
for those samples recognized as Vertebraria on the basis of their microanatomical features; thus, he designated his samples and those of Walton \& Wilson, Sen and Pant as $V$. gondwanensis.

Schopf (1965) described a petrified specimen from the Ohio Range, Antarctica (middle to upper Permian), basing for the first time such a determination only on microanatomical details, without including data on external morphology. In his reconstruction of Vertebraria, he did not indicate a massive central column as several earlier authors had done but he did indicate a longitudinally extended, irregular gap (Text-Fig. 1-c) connected with the aliform radial cavities between the wedges. The transverse outline of the central gap varies at different levels depending upon the way in which the wedges end in the center of the axis. He further commented that all previous authors, except Surange \& Maheshwari, had postulated a solid central core of xylem in the axis which he did not see also. Schopf named the Antarctic sample Vertebraria indica Royle emend, adding a diagnosis based on the microanatomy. In his work he considered Tordoxylon steinspruitense Kräusel as having the same structural plan as that of his sample, and thus he referred the South African specimen to the genus Vertebraria as $V$. steinspruitense (Kräusel) Schopf n. comb.

The reconstruction of the axis of Vertebraria of Schopf was novel in that it showed a central core that was variable and not massive. With respect to this point there remains a question, since Gould (1973) in describing his Australian samples presented results having substantial implications. His pieces of wood represented various growth stages which, when sectioned clearly showed the massive central column that early authors postulated previously. As shown in his ilustrations, this central massive column is occupied by primary xylem with exarch "loci" of protoxilem. From this core 4 to 7 arms of secondary xylem radiate (Text. Fig. 1-c) with radial gaps separating them. A periderm surrounds this stelic plan in the younger stems whereas a considerable secondary growth occurs as a continuous cylinder in older stems (cf. Pl. 9-I: Figs. 3-5, 7-9; Pl. 9-II: Fig. 9 II of Gould). $\mathrm{He}$ also showed true transverse xylem platforms connecting pairs of wedges at different intervals along the length of the axis. Gould's structural plan was similar to that inferred by Oldham (1897) which although repeatedly mentioned in publications, had never been so clearly demonstrated as by the microanatomical studies of Gould (cf. his Pl. 9-I: Figs. 7-9).

Paleoanatomical research on vertebrarian axes was now rich with many data, which posed new questions: do the structural sketches of Schopf (1965) and Gould (1973) represent different types of plant axes or merely ontogenetically separated parts of the same plant? Do these results suggest generic diversity within a complex of plants? And how accurately can one assign the same designation to plants having a demonstrated structural diversity, many of them being collected from distant occurrences throughout Gondwanaland?

In a third approach to vertebrarian research, Plumstead (1962) attempted an up-to-date synthesis of the subject. She described compressed samples from three localities in Antarctica and commented on the different general structural arrangements presented by Solms-Laubach (1861), Oldham (1897), Walkom (1922) and her samples which had a central xylem colum, while those of Walton \& Wilson (1932), Sen (1955, 1958) and Pant (1956) did not. She made a new reconstruction of Vertebraria similar to that shown by Oldham (1897) but she added sucessive oval openings along the lenght of the axis. She also asked: a) "wether each wedge was a separate stele with a surrounding band of panchyma" and b) "did Vertebraria represent a southern experiment in polystelic plants, contemporaneous with northern hemisphere Medullosae ?" I suppose that in the near future we will have evidences on which to base our answers to these questions.

Two important works by Pant \& Singh (1968, 1974) followed Plumstead's and also attempted to synthesize the main results up to that time. In the first of these, Pant \& Singh re-examined the type-specimen of Vertebraria indica Royle 1939 from the Britich Meseum of Natural History. They compared it with approximately 250 species from the Giridith and Raniganj Coalfields, in India. They worked mainly with longitudinal sections of the compressed axes and concluded that 
the range of inter-specific variation was still not sufficiently known to warrant species other than Vertebraria indica. This conclusion was probably a consequence of the difficulty they had to obtain peelled transverse section as well as longitudinal sections throught the gaps of the compressed axes.

TABLE I

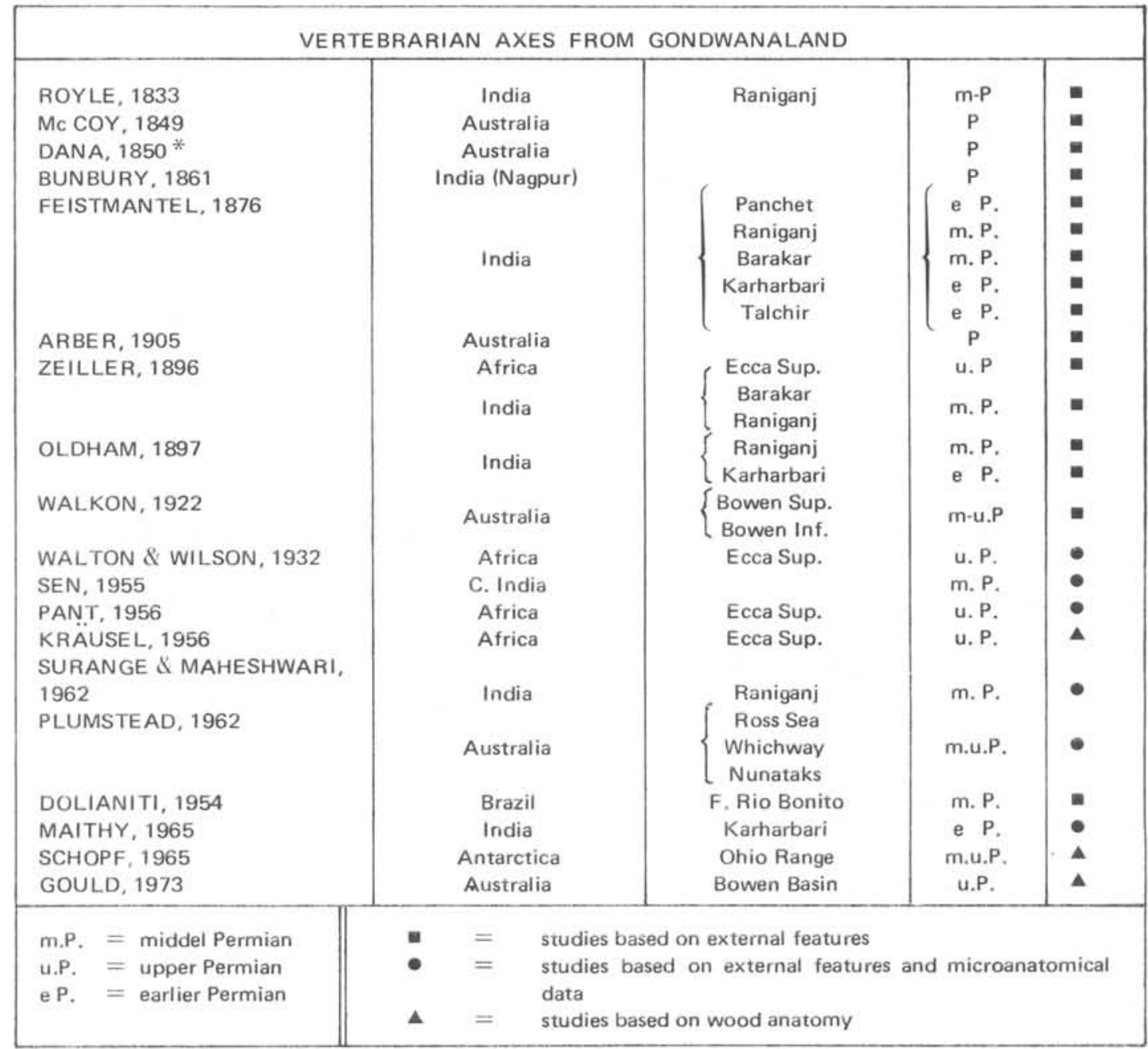

In their second work Pant \& Singh (1974) analysed the antomical features of approximatelly 130 specimens of glossopteridean shoots, with connected foliage. They concluded that although the surface features of most of the axes which beared leaves of Glossopteris (or Gamgamopteris) were different from those of Vertebraria, the structure of the xylem in those axes was closely comparable with those of Vertebraria, so that leafy shoots may lend further support to their identity. To their results, three following statement by Mainthy (1965) may be added: "As has been rightly pointed out by Surange \& Maheshwari (1.c.) Glossopteris is not a single genus, but a complex of many genera (Surange

* in Feistmantel, 1876 
Saivastava, 1956) and hence the axes of these genera might have been different".

Finally one can suppose that the authors, in studying the vertebrarian types of axes have adequately dealt with different xylic-plans, although all of these plans may be assembled within a single broader unit based on their common stelic configuration and microanatomical affinities with glossopteridales shoots; wether the features of a classical segmented Vertebraria axis are those of the internal stele as suggested by Walton \& Wilson (1932), Pant (1956), Pant \& Singh (1973) there remains the unsolved problem of the variety of the external aspect of these petrified samples.

Modern authors have placed in the genus Vertebraria petrified samples that show a very clear xylem core with radiating arms as well as specimens with the tips of the wedges ending in a lacunar core (or in a supposed pith); this assumption bring about new complications.

We can group described specimens showing a vertebrarian type of xylic plan into three main groups (Table 2).

TABLE 2

\begin{tabular}{|c|c|c|c|c|}
\hline \begin{tabular}{l|}
- \\
\\
0 \\
0 \\
$\frac{\pi}{0}$
\end{tabular} & $\begin{array}{l}\text { BUNBURY } \\
\text { OLDHAM } \\
\text { WALKON } \\
\text { PUMSTEAD } \\
\text { GOULD }\end{array}$ & $\begin{array}{l}(1861) \\
(1897) \\
(1922) \\
(1962) \\
(1973)\end{array}$ & & $\begin{array}{l}\text { trations showing a central massive } \\
\text { with xy!em radiating arms separa- } \\
\text { by gaps }\end{array}$ \\
\hline \multicolumn{3}{|r|}{$\begin{array}{l}\text { WALTON \& WILSON } \\
\text { SEN } \\
\text { PANT }\end{array}$} & $\begin{array}{r}(1932) \\
(1955,1958) \\
(1956)\end{array}$ & $\begin{array}{l}\text { A supposedly massive central column } \\
\text { in the graphic reconstruction, or but an } \\
\text { admitted pith as discussed in the text }\end{array}$ \\
\hline $\begin{array}{l}\text { N } \\
0 \\
\frac{0}{0} \\
\frac{\pi}{0}\end{array}$ & $\begin{array}{l}\text { KRÄUSEL } \\
\text { SCHOPF } \\
\text { SURANGE \& }\end{array}$ & $\begin{array}{r}(1956) \\
(1965) \\
\text { MAHESHWARI (I) (1962) }\end{array}$ & $\begin{array}{l}\text { we } \\
\text { ce } \\
\text { ra } \\
\text { th }\end{array}$ & $\begin{array}{l}\text { ge-shaped xylem radiating from a } \\
\text { ral lacunar core; each wedge termi- } \\
\text { s or not at different levels within } \\
\text { longitudinal extended lacunar core }\end{array}$ \\
\hline \begin{tabular}{l|}
$m$ \\
0 \\
$\vdots$ \\
0 \\
$\frac{\pi}{5}$
\end{tabular} & \multicolumn{2}{|c|}{ SURANGE \& MAHESHWARI (II) (1962) } & \multicolumn{2}{|c|}{ an inferred pith } \\
\hline
\end{tabular}

Comments on anatomical features of stems and roots:

Given the importante of distinguishing between stems and roots in fossil samples, brief comments on the anatomical features of stems and roots are presented here. In stems leaf traces are one of the main anatomical featurs, but other structures sometimes appear which are in part similar to leaf traces as the adventitious root traces before maturing. Adventitious roots in stems have a par- ticular significance, from the standpoint of environmental interpretation. They are present in the samples described in here when we try to obtain much about their paleoecology.

When adventitious roots originate in axial organs their vascular cylinder generally has developed by the time the root is about ready to emerge through the cortex. The development of an adventitious root trace in the organ where it originates is normally that of a common root, when root cap has formed and the maturation of the three prima- 
OLDHAM, 1897

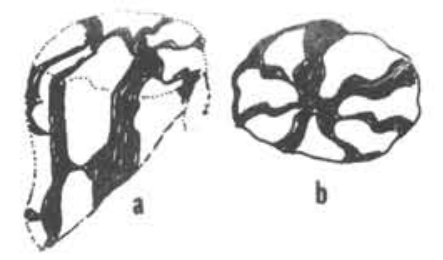

MAHESHWA RI, 1960
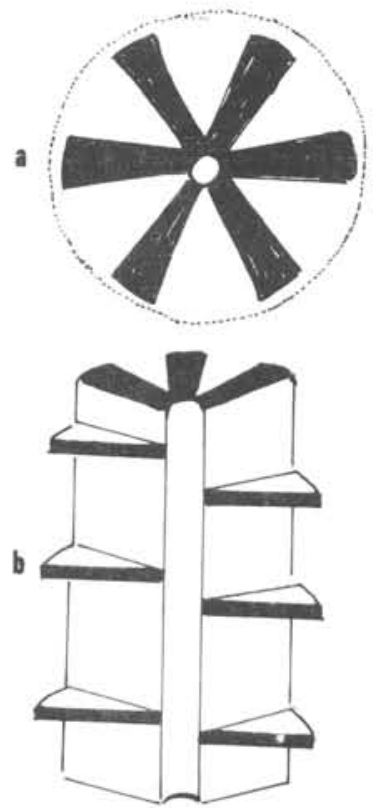

WALTON\& WILSON,

1932

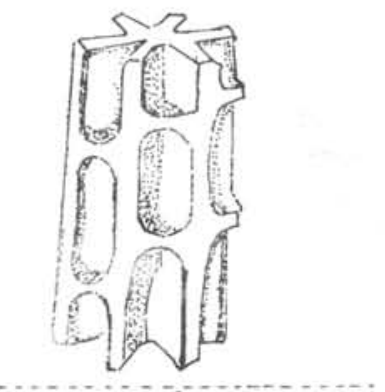

SCHOPF, 1965
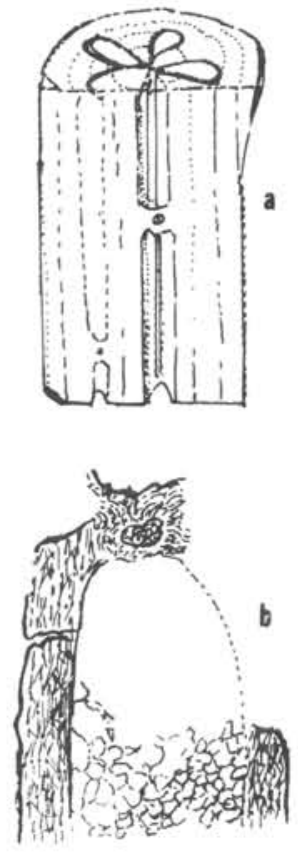

PLU MSTEAD,

1962

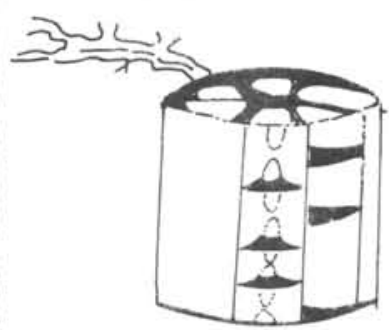

GOU L D, 1973
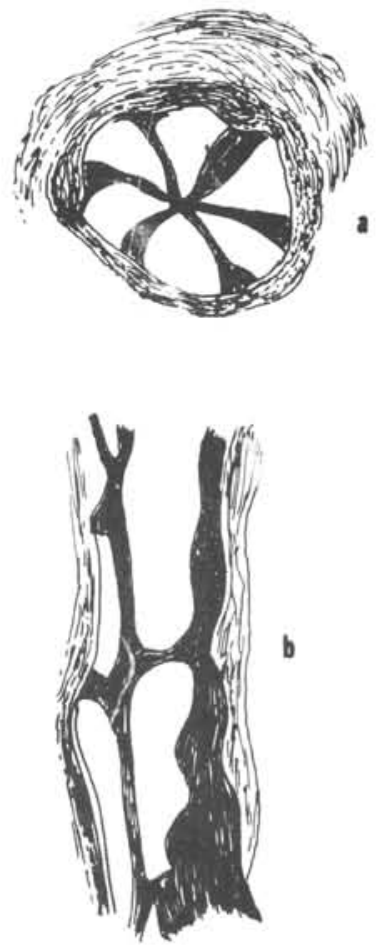

FIG. 1-c

Reconstruction drawnigs of the main xylic plans as seen by outhors, concerning Vertebraria axes.

ry regions has begun (Smith, 1936). A protuberance of the xylem core and a corresponding indentation in the surrounding tissues indicates the presence of the root primordium (Carlson, 1950). In the broad sense adventitious roots (Esau, 1961) are those which occur in aerial parts of the plants, such as branches, stems and leaves, or in subterranean stems, and also in mature regions of root organs (Fahn, 1974). In modern plants with a swamp habit they are common feature as well as in climbing plants, in rhizomes or in runner plants. 
In these, vegetative propagation usually occur by means of adventitious roots. Many warm climate trees send out roots from the branch or from the stems that remains free in the air until they grow downwards into the moist earth to serve as prop roots. If they attach themselves to another three or support they are said climbing roots. In dark florests and swamp environments where the lack in oxyegen generally occur the plants emit negatively geotropic roots serving for gas exchange (Clarck, 1933; Taylor, 1926; Esau, 1953). Concerning root organs, adventitious roots are ontogenetically different from lateral roots. These last always arise in the pericicle meristem or near the endodermis and never in the pith or in the woody body. Generally they are nearly opposite protoxylem loci: Thus, there are found as many vertical rows of lateral roots as there are protoxylem loci in the mother root. In this sense lateral roots are said endogenous in origin. Stem appendages are said exogenous because they arise in the apical meristem. During the stem increment in lenght they arise at randon in the vascular body of the plant. They may be initiated in nodal or inter-nodal regions (Carlson, 1938), in the pith or within indeterminate tissue of the vascular bundles (Smith, 1936) in the pericicle, cambium or in the cortical layers of the organs. In this sense, they may be endogenous or exogenous in origin.

As demonstrated by Morrison (1953) apart of ontogenetical differences between roots and stems there occur a sort of changeable histological features as a result of adaptation to environmental factors. Exposure of roots to dry air and to sunlight stimulate the lignification of vessels and fibers, while stems placed underground show larger and more numerous thin walled vascular elements, fewer fibers, more parenchyma, larger and more abundant rays per sq. $\mathrm{mm}$. (Eames \& Mc Daniels, 1947) and less distinct growth rate (Fahn, 1974).

With these statement we are able to conclude much about enviromental conditions of our fossil samples and the site where they lived.

\section{SPECIMENS FROM THE IRATI FORMATION}

Research on permineralized wood samples from several localities in the Irati Formation, State of São Paulo, Brazil, adds several anatomical data to the understanding of the structural stelic-plan of axes within the vertebrarian complex. These samples show many anatomical features not yet described, thus the inclusion of them within the mentioned complex as independent genera. These petrified pieces of wood do not show any of the external morphological features, upon which the genus Vertebraria was stablished; their high content in organic matter are favourable to evidence the microanatomical features. The type of fossilizarion was the permineralization and deposits by silica solutions occur upon the walls of the elements, so that the anatomical features were so aparent that they could be observed in serial thin sections.

Externally two of these samples (GP/3T. $113 ; \mathrm{GP} / 3 \mathrm{~T} .114)$ are striated by very thin parallel lines; one of them show the remains of a forked structure (GP/3T. 113: Pl. VIII, Fig. 51$)$ and the second is a curved axis (GP/3T. 114; Pl. XI, Fig. 64 ). Sample GP/3T. 110 is lobed and embedded in a dolomitic matrix (P1. I, Fig. 4-A), Samples GP/3T. 111 and GP/3T. 112 (Pl. IV, Fig. 20 and Pl. VII, Fig. 39) are approximately cylindrical, but sample GP/3T. 112 has alternate elliptical scars $0,8 \mathrm{~cm} 1,4 \mathrm{~cm}$ wide. Sample GP/3T. 109 resembles a curved branch with several alternate small round scars, $0,8 \mathrm{~cm}$ wide (PI. I, Fig. 3 ). Most of the samples have asymmetrically situated geometrical axes, but in the samples GP/3T. 111 and GP/3T. 112 they are symmetrically centered.

On the basis of their anatomical features two of the samples (GP/3T. 109, GP/3T. 110) are closely similar to the genus Tordoxylon Kräusel 1956; their asymmetry, like that shown by some modern lianas, as well as the lack of primary structures peculiar to roots, emphasize a climbing nature for them, in which the free surface has a large amount of secondary growth and a minor growth rate occur in the portions that lie over a support; two other samples may be compared even to some shrubs or to some runner plants 
that lie in the mud of semiaquatic environments, swamp-places, in littoral conditions and places where the soil is periodically inundated and where some trees can produce aerial roots from the stem or branches.

With regard to Table 2 of this work the presently described Brazilian samples are distributed through the Groups 2 and 3. To what extent can one consider these differentiated anatomical forms, as ontogenetically related parts of the same and widely dispersed genus, and designate all them under the name Vertebraria Royle 1839 ? It may be shown in the future that all these samples, with similar stelic configurations are interconnected parts of the same plant, but this assumption was not proven yet. Presently the only sure indication is that there is a complex of genera concerning the Glossopteridales; as has been emphasized by the Indian paleobotanists (Surange \& Maheshwari, 1962; Maithy, 1965) such complexity or generic diversity should refer to stems. According to this statement new generic names were given to the Brazilian samples, which showed affinities with respect to those samples classified in the broad taxonomic unit Vertebraria Royle 1839, but they were distinguished on the basis of: a) occurrence of nodes; b) occurrence of an incipient pith; c) a peculiar manner of issuing adventitious branches. Neverthless all these samples are closely related by: a) a common wedge-shaped stelic-plan; b) parenchyma cells scattered in the rings; c) cambial activity in these parenchyma cells and also in the cells of vascular rays; d) a very peculiar differentiation of vascular pitting on the walls of the tracheids as a distinctive arrangement, as compared with the two main types of arrangements described by Marguerier (1973).

As to this last feature, such a configuration of pits appears to be confined to a restricted group of Gondwanian plants, specially several described glossopteridean shoots and vertebrarian axes. In describing their vertebrarian axes such type of arrangement has been reported by authors as pits in groups, several pits at the same level, irregular, in horizontal rows, single row widely spaced (cf. Walton \&Wilson, 1932; Surange \& Maheshwari, 1965; Gould, 1973 and others). When Seward \& Wal- ton (1905) described samples from Falkland Island, one of them was classified as Dadoxylon bakeri which showed a small pith with acutely terminating wedges. On the radial walls of the tracheids they commented on an unusual arrangement of pits, as "stellate groups", wich did not resemble the pitting arrangements known in the woods of "Dadoxyla" group. Without much comment they indicated Callixylon oweni Elkins as showing a similar organization. Marguerier (1973) reviwed the results of research on Gondwanian woods, and noted an accurate association of anatomical features related to main groups: the first, in which the associated features were primitive, resembling those of Cordaitophyta (multiseriate radial pits, arancaroid in type, eyepores); the second, showing variations with respect to the arancarioid arrangement (abietoid radial pitting, crassules, groups of pits or pits arranged in two spaced radial rows).

Marguerier (op. cit.) estabiished the morpho-genus Australoxylon to include pieces of secondary wood having these features and collected from Gondwanian formations. As for glossopteridean shoots she commented on some similarities and convergence of forms; she added observations on the base of Surange \& Maheshwari's results (1962): “Cependant il est difficile d'établier des affinités precises car ce groupe est encore assez mal connu quant a l'anatomie de ses représentants".

Today we have a satisfactory amount of paleoanatomical studies on Vertebraria axes, as well as on glossopteridean shoots, and we can compare Walton \& Wilson (1932: Pl. II), Sen (1955: Pl. 1), Pant (1956: Pl. I), Surange \& Maheshwari (1962: Pl. 1); Maithy (1965: Pl. 5); Pant \& Singh (1968: TextFig. 2: D, E, F, G.; Text-Fig. 3: D, E.; Pls. 125-126); Pant \& Singh (1974: Text-Figs. 6 (A, C, D, E); 9 (A); 10 (6) Gould (1973: Pl. 9-II) and the plates of this work (Pl. 1: Fig. 2; Pl. III: Fig. 15; Pl. VI: Figs. 30-33; 35-36; Pl. VII: Figs. 44-45). Conclusions can be made on the rare kind of unusual pits organization in these axes. It seems that a diferentiation occurs on the radial walls of the tracheids, where evenly spaced groups of pits appear preferably in early wood. These are not irregular groups, but rather they have 


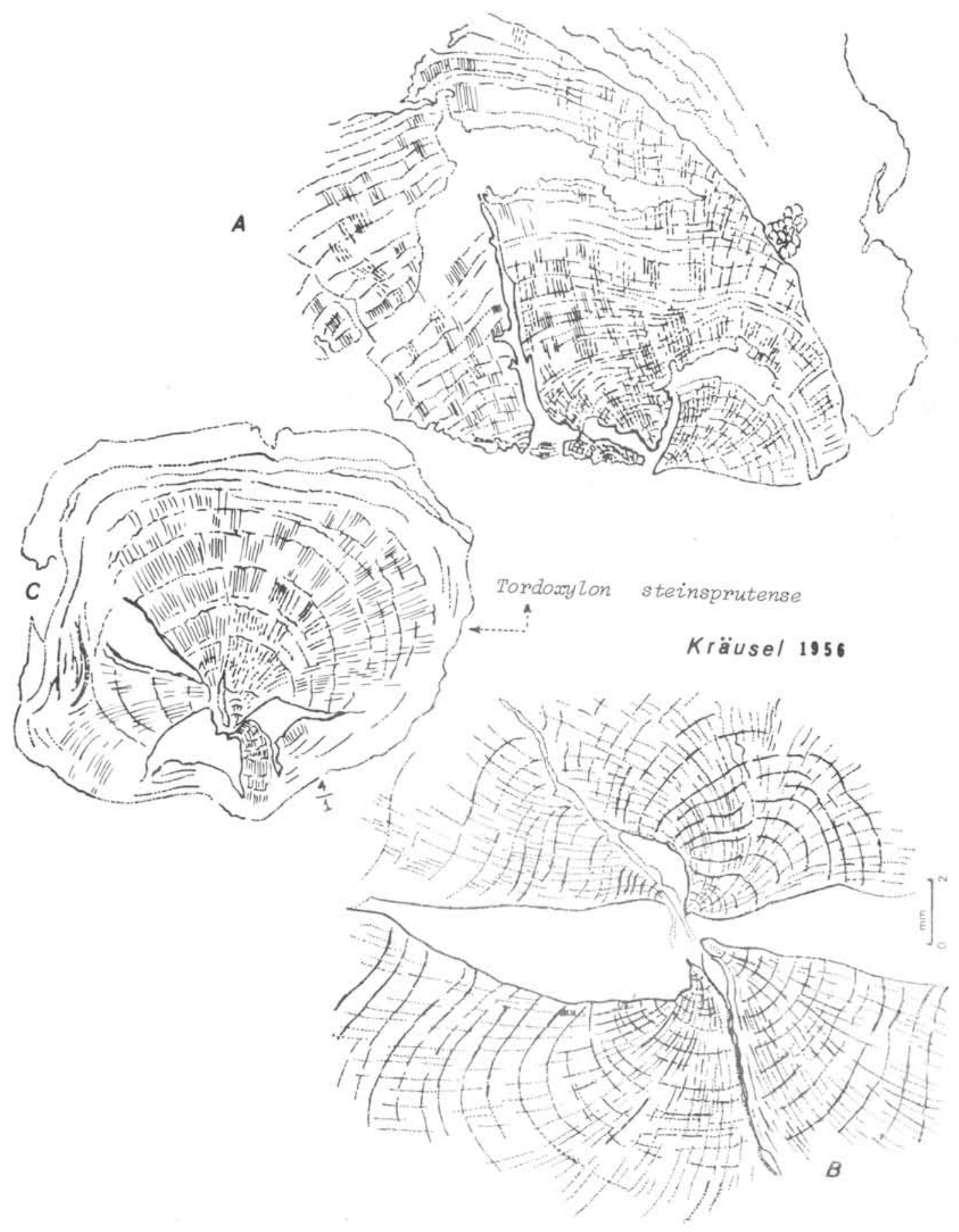

Fig. 2

Sketches (wild/47A Lupa) from transversal sections of two brazilian samples (A, B) to be compared with the South African specimen (C). Note the assimetric outline in the all specimens.

a virtual geometric center (P1. VII; Fig. 40), or there is a central pit in each group with a number of pits distributed around it (Pl.
VII: Fig. 45). Each group resemble a rosette-geometric form; the groups are distributed along the lenght of the radial walls 


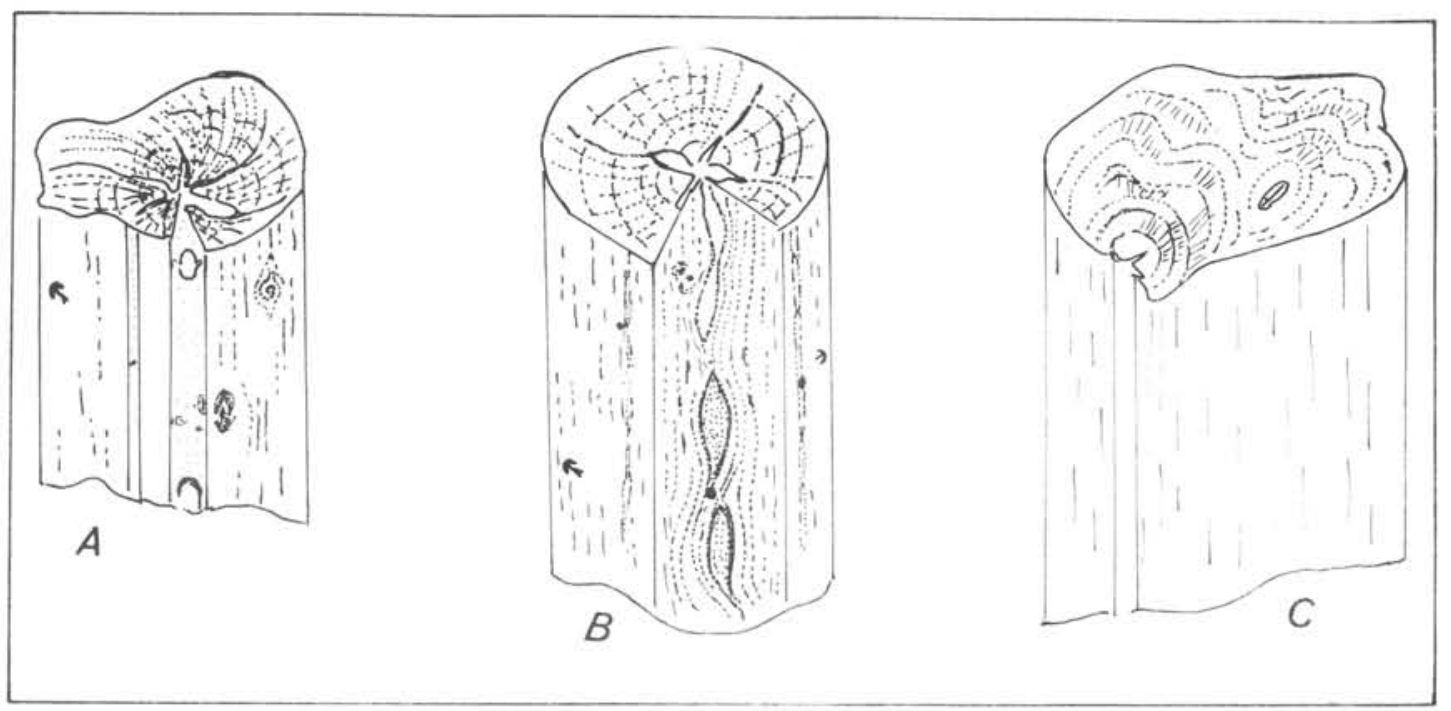

FIG. 3

Reconstruction-drawing of three types of xylic plans, showing affinities with Tordoxylon Krausel 1956; A: TORDOXYLON; B: MYELONTORDOXYLON; C: PARATORDOXYLON.

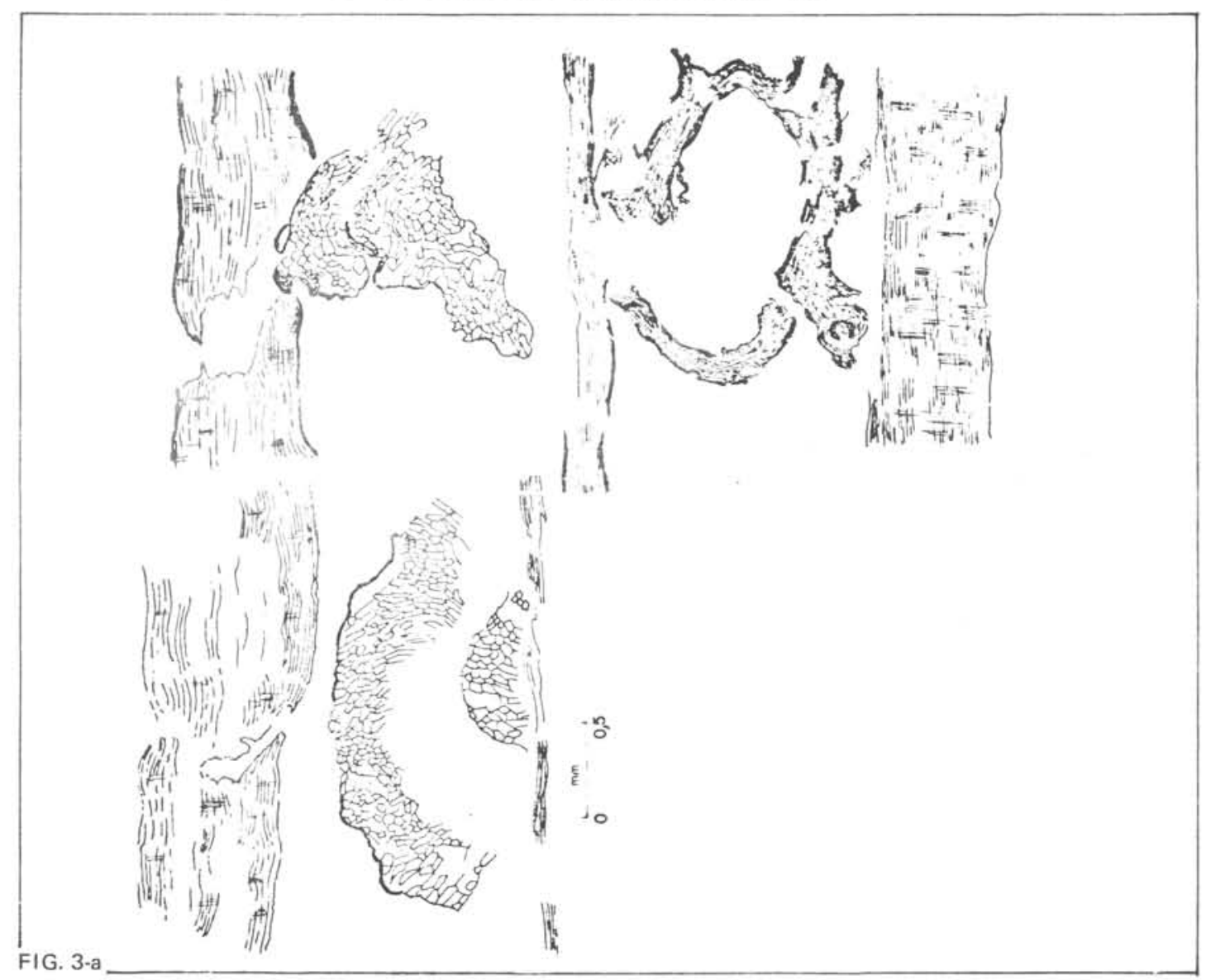

Sketching drawing (wild/47A Lupa). Residual structures trought the longitudinal lenght of the central gap in the brazilian specimens. 
of the tracheids: groups of two opposite pits plus an isolated one result in a rosette-form of three-elements (PI. VI: Fig. 30); groups of doubled pairs of alternate pits result in a rosette-form of four elements (P1. VI: Figs. 31-33); Pl. VII: Fig. 44); one central pit and a doubled pair of alternate pits around it results in a rosette-form of five elements etc. (P1. VII: Figs. 31, 34; P1. VII: Figs. $44,45)$. Futhermore there are two to seven opposite pits in horizontal evenly spaced rows or in doubled horizontal evenly spaced rows. (Pl. VI: Fig. 33); secondarily appear tracheids with spaced pits in a single row (Pl. III: Fig. 16) or showing an approximate arrangement of the araucarian type (Pl. VIII: Fig. 50).

Hence, the main feature is not the rosette aspect in the pit groups, or the number of pits per group, but the conservative space between neighbouring groups of pits. One sample (GP/3T. 113) has the grouping aspect only on tracheids of late wood (P1. X: Fig. 60) whereas in the early wood the pits are closely arranged as in the araucarioid type of arrangement (Pl. VIII: Fig. 50). This piece of wood is forked having remains of an adventitious appendage (PI. VIII: Fig. 49) so that a clear interference of cambial activity had occurred, during the life time of the axis to issue new vascular elements to the branch; this activity could influence the pitting arrangement on the walls of the tracheids.

The style of pitting arrangement within the vertebrarian axes approaches that of the second group of pit arrangement recognized by Marguerier (1973), but due to the frequency of the stellate groups and the spaces evenly repeated between groups it represents a peculiar style of pitting, among this complex of Permian woods.

\section{DESCRIPTION OF SAMPLES}

The first group of samples is approached to the xylem plan showed by Tordoxylon steinspruitense Kräusel 1956 and can be included in the Group 2 of Table 2 of this work.
Samples: GP/3T. 109, GP/3T. 110: Col. Departamento de Paleontologia e Estratigrafia, IG/USP.

Locality: AF. GP/8. IR/S.P.: Pedreira Moura, Município de Piracicaba, São Paulo.

Age: Permian (Irati Formation).

Type-species: Tordoxylon steinspruitense Kräusel.

Tordoxylon sampaulense n. sp. (Holotypus: GP/3T. 109; PI. I-III)

Description: To illustrate his specimen from the Beauford Series upper Ecca of South Africa, Kräusel (1965) showed an asymmetry in the growth of the vascular cylinder. The Brazilian samples also have an asymmetric outline (Text Fig. 2: Figs. A, B, C; Pl. I: Figs. 1, 5; Pl. III: Fig. 11). In the illustrations one can see the result of asymetric growth indicated by 4-6 xylem wedges, in which acute tips terminate around an offset geometric center. This means that the stem is not compressed, but that each wedge had different growth increment. According to this each acute xylem wedge tenninates at a different level in the irregular longitudinally extended central space, which communicates with the radially extended spaces between the wedges. A feature is clear both in the African specimen as well as in the Brazilian specimens: each xylem wedge grows independently from the other in its earlier stages of growth and after they form a single body during their secondary growth. Plate I: Figs. 1, 5 and Pl. II: Fig. 10 show cross-sections of the samples: in Fig. 1 two major spaces are seen between the wedges with about $7-7,5 \mathrm{~mm}$ in its radial length and $1,5-2 \mathrm{~mm}$ in width; there occur also two minor gaps with about $5,5-6 \mathrm{~mm}$ in length and $0,8-1 \mathrm{~mm}$ in width. These last have their margins joined at levels in their radial length. On the right, above we can see a fifth and deflected one, as the wedges are, with its margins almost entirely joined nppearing as a curved line. The cut-sections showed that these spaces become broader or thinner at diferent levels 
along the length of the axis according to the torsion of it. (Text-Fig. Pl. I: Fig. 3).

In the major spaces between the wedges there are still remains of structures similar to thin-walled cells which suggest that they appeared during the life time of the plant being flegraded by the torsion of the axis. In this sense they could be related to the depparture of appendages. Several of the wedge tips are well preserved and they show from near the center of the axis toward its outer margin, a progressive increment in the tracheidal size, the elements becoming larger toward the outer margin of each wedge. Thus, one can assume that the tips of the wedges represent the protoxilem initials whereas in this case nothing about structures like the primary body of roots can be reported at any of the cut-levels; it would be accetable to assume that few parenchymatic cells existed in the central space as an incipient pith. From the initials of the wedges to the periphery of the axis one can see well defined rings (Pl. III: Fig. 11) asymmetric in their outline as asymmetric is the woody body. They are waved in shape by the occurrence of included parenchymatic cells. Pl. VII: Fig. 41 shows a general aspect, which concerns to all of the described samples in this work.

Along the lenght of the axis longitudinal cut-sections did not show in the radial spaces the classically described xylem platforms, concerning a typical vertebrarian axis, or short members (Gould, 1973; Shopf, 1965) connecting adjacent wedges. With respect to the African specimen Kräusel (1956) also did not refer to any structure connecting adjacent wedges; in the Brazilian samples (GP/3T. 109, GP/3T. 110) one can observe unusual structures displayed between the wedges, but not true platforms, in the sense of Gould (1973). They are residual structures of ruptured cellular bodies occuring at levels between the wedges (Pl. III: Figs. 12-14; Pl. VI: Fig. 38). Several of these structures are oval, but many of them are varied in form. (Text Fig. 3a) Plumstead (1962) indicated oval openings along the length of the central axis of her Australian samples of Vertebraria and this feature may be paralleled with the residual structures presented by the Brazilian samples. In Pl. III: (Figs. 12-13) it is seen a node in the margin of a longitudinally extended space. The node is settled paralell to these structures interpreted as residual, so that one can assume them to be related to the departure of a trace, being ruptured after these traces had passed out to the xilem body. These structures are cellular, but their cells are not typically parenchyma cells since their walls are as thick as the tracheid walls. They represent a type of transfusion tissue laid down at places as altered protoxylem. In modern plants this tissue is preferably restricted to the vascular system of leaves of gymnosperms and in fossil plants it occurs in Progymnospermopsida, Pteridospermopsida and also few Gymnospermopsida stems; sometimes in these groups they form the entire vascular body of the plant (Cf. pp. 131-135 of Bureau, 1954). According to the assumption of several authors transfusion tissue is a sort of alteration of protoxilem elements as an adaptative change to stock water. Both in sample GP/3T. 109 and sample $\mathrm{GP} / 3 \mathrm{~T} .110$ nodes appear in several stages of maturation, being those in the earlier stages of formation near the pith margin. But the maturation of the bundles from few of the nodes is different. In several of them they continue as single or doubled bundles throught the woody body. Plate II (Figs. 6, 7) shows two of these nodes longitudinally cut and Fig. 8 (Pl. II) shows a node with a doubled bundle cut in transection, when running through the woody cylinder. Its maturation (PI. II: Fig. 9) indicate a nature of traces inherent in stems (leaf traces). Pl. I (Figs. $3,4)$ shows the samples cut at several levels, so that the features could be followed along the axis. Few of the bundles could show outlines of a root cap, and differentiated root body of an adventitous appendage $(\mathrm{Pl}$. II: Fig. 10), since their early maturation near the central space's margins. Thus, the differentiation of two types of maturing nodes (several of them bearing leaf traces and other bearing adventitious root trace) clearly outlined in the same axis, lead one to find a conformity in the assumption that a swamp plant (climbing or runner) is being dealt with and having the anomalous outline of a stem, in spite of its root-like wedged transversal view.

On the radial walls of the traclieids 

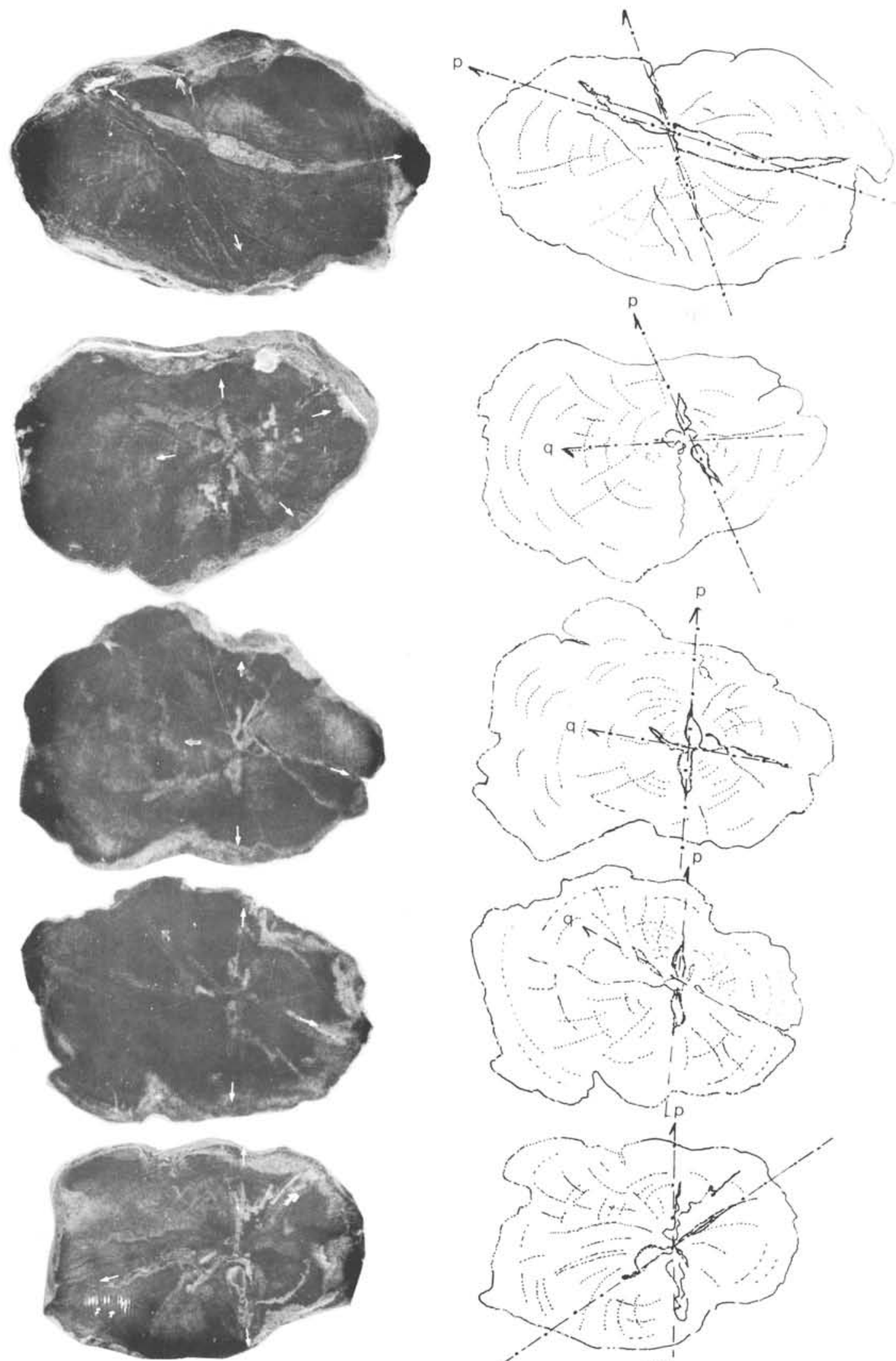

FIG. 4

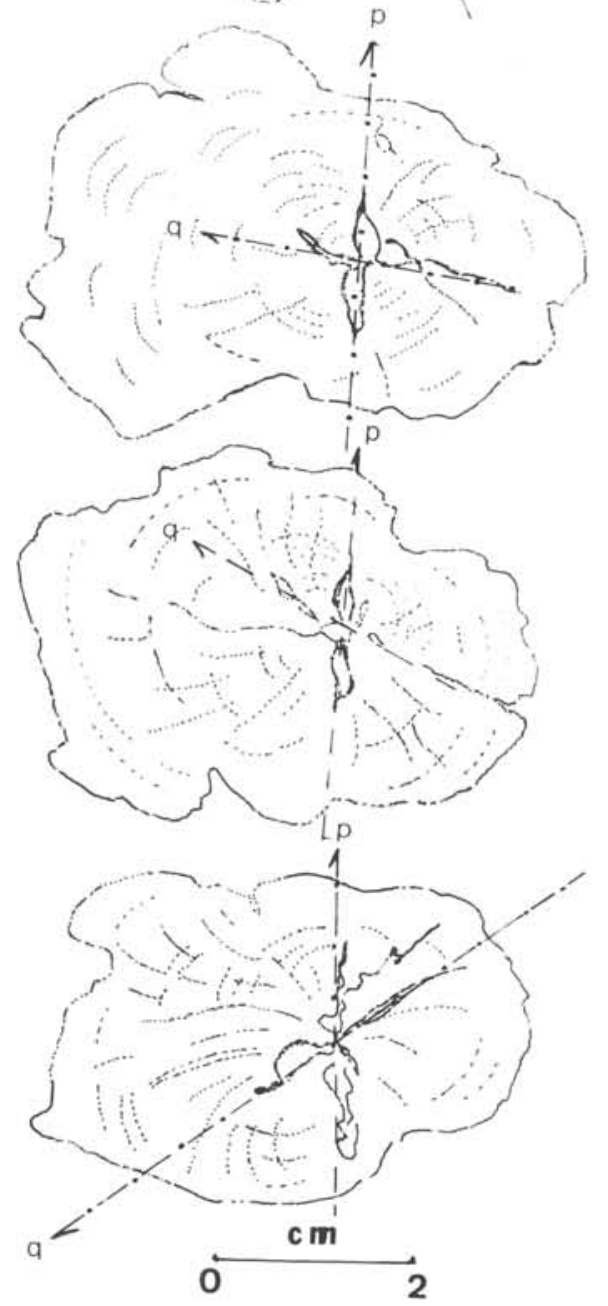

Transversal sections of the sample GP/3T.109 cut at different levels and showing the torsion of the axis. 
the pitting arrangement is peculiar because of the spacing between groups; such feature indicates an unusual type of pitting differentiation. When the pits are in one row they are separated and when occur more than one row, they form groups of $2-6$ elements, acquiring a rosette configuration, as groups approximately separated by regular spaces. In these samples also appear spiral thickening in the late wood tracheids, specially in sample GP/3T. 109 (PI. I: Fig. 3) which is like a bent axis; one can conceive that this event is resulting of tension wood formation, accordingly to the torsion of the axis (IAWA) as ilustrated in Pl. III: Fig. 16. Cross-fields (PI. III: Fig. 17) have several rows of pores, varied in form. They look like sand grains in their outline and are different from those named "oculipores" more frequent in araucarian woods. That is the reason because I describe them as grainpores. Sometimes these are grouped in a rosette form in the field.

Discussion: The structural outline of these samples can be explained in part by comparing their growth with some anomalous type of growth in modern lianas. Concerning their primary vascular structures, we can compare them with the primary vascular system of the modern Ephedra (Madsen \& Steeves, 1955), but the resemblances here mentioned are only paralleled. Ephedra is xerophilous in habit and the stem tends to be ridged and grooved and the nodes make in it the appearance of a jointed aspect. During elongation one can see a girdle of nodal wood, and authors consider that leaf traces would pass out through it. In the nodal girdle of Ephedra there occurs a type of tissue interpreted as transfusion tissue, by the shortening of their vascular elements. In Ephedra this anatomical feature is considered as anomalous, but with respect to the structure of these fossil samples it may be suggestive, although their mutual taxonomic differences.

As discuting the nature of the Brazilian samples two major features could emphasize their root nature: the poliarch aspect inherent in the stele and the radial spaces between the wedges. These spaces could resemble those larger rays of roots departing from near the primary structures, but also they could be concerned to the departure of leaf-traces. The lack of a primary core as in roots, with regard to these fossil samples seems to be an ontogenetical feature and not accidental. If the primary root structures with their exarch protoxylem "loci" had been degraded during the maturation of the organ, the acute terminating wedges, at last would have had another outline, being the tracheids of secondary growth or arranged around the archs of the primary core or they could issue radiating arms from this core as in the vertebrarian axes described by Gould (1973). The cells of parenchyma with a cambial activity in the rings, the asymmetry of the wood cilynder and the different nature of maturing traces in the wood are against a root nature for the axis and emphasize a swamp stem nature for it (runner or climbing plant).

Outlines of nodes were reported in the description of the sample from Karroo named Tordoxylon steinspruitense (cf. Pl. 2, Fig. 3 of Kräusel, 1965). The illustrations show remains of these structures in the woody body near the "pith" margin and now we can understand these structures as being adventitious root-traces which were in their earlier stages of formation. (compare Kräusel's illustration with Pl. IV: Fig. 9, in this work). Unfortunately Kräusel could not define the nature of those traces because of the small size of his sample, whereas his Pl. 2 (Fig. 3) show the tracheids between two adventitious root-traces as curving from one margin of the first node to the other margin of the second, as usually occur in the Brazilian samples. If these traces both in African specimen as in the Brazilian specimens had their course through the spaces between the wedges, they could have been defined as lateral roots and the organ as a root, but these traces had their course through the woody body, hence they are clearly adventitious root-traces as common in stems as in roots. On the other hand the Brazilian samples have another type of well preserved maturing traces, whose maturation is similar to those of stems; under this point of view they differ from $T$. steinspruitense, and also by those cellular residual structures occuring at levels between the wedges. If in the present such structures can not be well seen as true xylem platforms or trusses they will 
be understood if we conceive the departure of traces from them, and residual structures being then ruptured remains; as an approach they also can be seen as ontogenetical stages of maturation within the woody stems, which have their xylic-plan within the complex-set of the vertebrarian axes. Schopf (1965) considered the genus Tordoxylon as synonim of the genus Vertebraria, but the present research on the Brazilian samples show that we are dealing with an approached, but definite and independent genus.

\section{Genus Tordoxylon Kräusel 1965}

Type-species: Tordoxylon steinpruitense Kräusel 1965.

Generic-Diagnosis emend: asymmetric vascular sections seen in the transverse view; spaces separating acute terminating wedges in the offset centered axis; spaces changing in form and size according to the torsion of the axis; nodes in the woody body showing different types of maturation as single or doubled bundles running through the xylem cylinder, or as bundles which early maturate as adventitious root-traces; pith degraded in a lacunar core; spaces between wedges showing ruptured structures, as remains of matured platforms, after the departure of traces.

\section{Tordoxylon sanpaulense $\mathbf{n}$. $\mathbf{s p .}$} (PI. I-III. Figs. 1-16; Text-Fig. 2-4)

Diagnosis: wedge-shaped sections as typical stelic configuration; 5-6 acute terminating wedges around the offset center of the axis; different amount of growth in each wedge by the torsion of the axis and resulting asymmetric outline in transverse views; 4-5 spaces, aliform in their aspects, separating the wedges; spaces interconnected by means of the lacunar central core of the axis; preserved tips of the wedges showing smaller tracheids near the center of the axis and a progressive increment in their size toward the external margin of the vascular cylinder; cambial activity of parenchyma cells included in the rings and resukting wave like outlines of the rings. Radial walls of the tracheids showing groups of pits evenly spaced; spiral thickening associated with bordered pits in the late wood by the tension wood formation during the elongation and torsion of the axis; small bordered pits about $3-4 \mu$ in diameter; several small pores in the cross-fields, 4-5$6 \mu$ wide, without discernible borders and varied in shape as grains ("grainpores") and not ordinarily as "oculipores"; uniseriate short rays, 1-3 cells high; different types of maturing bundles from nodes; single or doubled bundles running through the woody body and bundles which early had matured as adventitious root traces; residual cellular formations like ruptured platforms of transfusion tissue, between wedges at different levels as well as nodes in their earlier stages of maturation in the wood margin at these levels. Gymnospermic type of wood wich resemble lianas by the asymmetry and resulting microanatomical features by the torsion of the axis.

\section{Myelontordoxylon $\mathbf{n} . \mathrm{g}$.}

Generic Diagnosis: Symmetric outline in the vascular cylinder; wedges with truncated tips; a core of primary structures is absent; an incipient pith is present. General features comparable with those of the genus Tordoxylon.

Samples: GP/3T. 111 and GP/3T. 112 - Depto. Paleontologia e Estratigrafia, IG/USP. Locality: Pedreiras Maluf e Vitti (AF/GP 80. IR/S.P.) near Piracicaba, São Paulo, Brazil.

Age: Permian (Irati Formation).

\section{Myelontordoxylon vittii $\mathbf{n}$. g., sp.}

Holotypus: GP/3T. 111 (Pl. IV-V: Figs. 18-37; Text-Fig. 3,5)

Description: The surface view of this sample shows an approximatelly symmetrically located center of the axis (Pl. IV: Fig. 20). As the samples described in the genus Tordoxylon in here also occurs the wedged-shaped stelic configuration, but the tips of the wedges are truncated and being continued by scattered cells of parenchyma (PI. IV: Fig. 18). Between 
the initials of the wedges also occur two major aliform spaces, with $0,5 \mathrm{~mm}$ in lenght and two minor with about $0,3 \mathrm{~mm}$ in length. These spaces seem to be incipient gaps, less discernible than those described in the first group (Pl. IV: Fig. 17). Newly we are being dealt with unusual features which progressively suggest us to discuss the nature of this axial organ. The cross sections of the sample show well marked rings (Pl. IV: Fig. 19) having included parenchyma cells in them. As mentio- ned before this is a general feature with respect to these groups of axes whose wedged stelic configuration is approarched to the vertebrarian stelic plan. The tangential sections (PI. VI: Fig. 37) show also a general feature among these samples; short (1.2 cells high) uniseriate rays. The radial sections show the general commented features concerning the arrangement of vascular pitting (Pl. VI: Figs. $30-33$; $35: 36)$ as evenly spaced groups having varied number of small bordered pits,
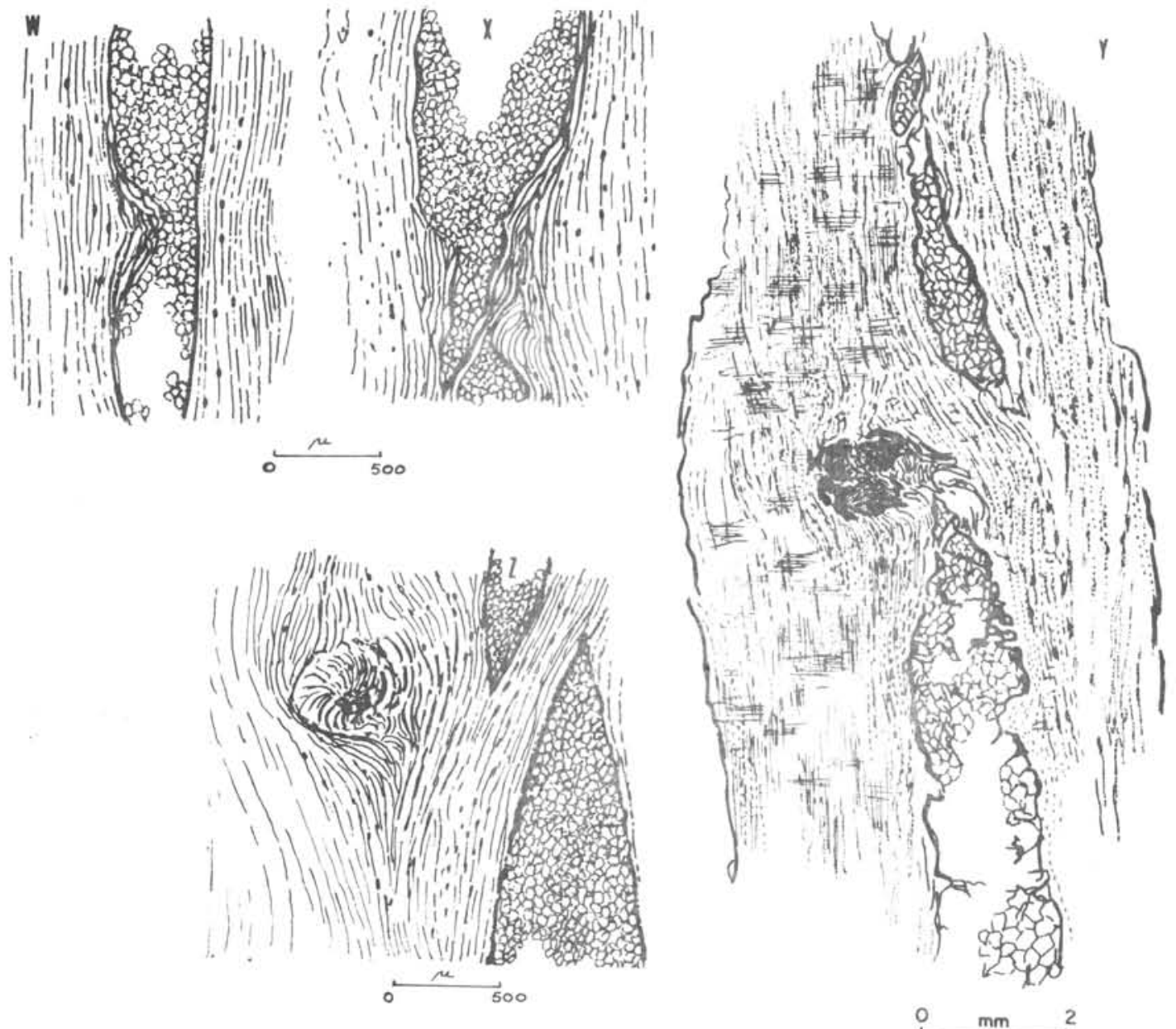

FIG. 5

Semi-diagramatic Sketh (Wild 47A - Lupa): pith constrictions caused by the tracheids crossing, from one margin of the pith, on the right to the other margin on the left: (Y). An adventitious root is originating and the parenchymatic pith is now represented as axial parenchymatic pockets. (W, X, Y, Z: Different fields along the pith). 
$34 \mu \mathrm{m}$ in diameter. In Pl. VI: Fig. 34 we observe the cross-fields showing pores with the aspect of grains and not as oculipores; sometimes these cross-field pores are arranged with a rosette aspect in the field. Near the pith or central parenchymatic spaces the features of these samples are original. Between two wedges there are not true xylem platforms or trusses, as "short members" with rootlet traces (Schopf, 1965; Gould, 1973), but a variation can be observed concerning this feature: during the elongation of the axis a constriction usually occurs in the parenchymatic spaces or small stellate pith; such pith constrictions are the result of the crossing of the tracheids from one margin on the right of the space over its other margin on the left (Text-Fig. 5). Consequently appear two separated parenchymatic pockets at this level in a same longitudinal line (Pl. IV: Fig. 19). At the upper end of one of these longitudinally extended pith pockets the parenchymatic cells provide the formation of one or more adventitious root-traces, which generally are oentarch (PI. IV: Fig. 22). These could be follewed by means of serial thin sections (Pl. IV: Fig. 21, 23: $a, b)$ which showed the early passage of the young root to the secondary xylem body, but still in this stage of maturation they appeared near the margin of the parenchymatic gap or axial parenchymatic pocket. In $\mathrm{Pl}$. V (Figs. 24 and 25) one can observe the maturation of the same trace into the secondary-xylem cylinder, till the formation of a young root, with its maturing tracheids, definite root cap and differentiated hystogens; Pl. V (Figs. 26, 27 and 28) show the same anatomical event of adventitious root traces origin, but in this illustrated case parenchymatic cells of the constricted pith provided the formation of two adventitious roots at the same level; later they separate in their pass out to the periphery of the stem.

Discussion: Sample GP/3T. 111 is original in its assembled features. Although it is well differentiated from the anatomy of Tordoxylon it has many anatomical aspects showing affinities, with respect to this genus and also with respect to the anatomy of Vertebraria; its wedged stelic configuration, pitting arrangement on the radial walls of the tracheids, cross-field pitting, short uniseriate rays, included parenchyma cells in the rings approach Myelontordoxylon vittii both as to Tordoxylon as to Vertebraria. As comparing Myelontordoxylon vittii to $T$. steinspruitense and $T$. sanpaulense we can observe that these last species had asymmetric growth of the woody cylinder as well as they did not evidentiate the occurrence of axial parenchymatic pockets like a pith as in $M$. vittii. If we compare Pl. 2: Fig. 3 of Kräusel (1956: p. 19) we will conclude that his illustration concerns to adventitious root traces in their earlier stages of formation, because they are similar to the adventitious root traces of $M$. vittii, although in Tordoxylon these roots had different origin if we compare the originating roots in the pith constrictions of $M$. vitti. With respect to $V$, indica described by Schopf (1965) we have a similar configuration of roots as in $M$. vittii, when they are observed in their earlier stages of formation, before passing out from the pith pockets to the woody body. Neverthless is still soon to present a judgement about the nature of the rotlets seen in the $\mathrm{xy}$ lem platforms of the vertebrarian axis as described by Schopf (1965) and by Gould (1973), since there is not till the present a clear documentation about the pass out of these roolets, if being of lateral type or of adventitious type of roots. Schopf's sample is more similar to $M$. vitii than Gould's samples, because these last have a massive core of primary xylem, with exarch protoxylem "loci".

Concerning $M$. vitti at the level of each pith constriction the tracheids are shorter than those of the woody body, and one can atribute to them a nature of transfusion tissue, the initials of the xylem being probably changed. The cambial activity in the pith at definite levels, as occur in the constructions, poses a significant question concerning the nature of these regions, as being nodal regions; the ocurrence of adventitious roots only at these levels suggests a stem nature. In stems, roots usually emerge from the pith at the level of nodes; adventitious roots in roots generally are laid down at any place in the root body. The lack of leaf-traces allied with adventitious root traces may be suggestive in two ways: in a swamp enviroment and in periodically inundated areas, shrubs and climbing plants with a xeromorphic habit, usually present adventitious roots and scarce leaves, and so, 
the lack of true leaf traces allied to the occurrence of adventitious root traces it is explained. Another assumption concerned to the same type of environments refers to runners and subterranean stems which may show the combined features described above.

Diagnosis: Myelontordoxylon vittii n. g., n. sp.

Holotypus: GP/3T. 111 - Depto. Paleontologia e Estratigrafia. IG/USP.

Symmetric woody vascular cylinder. Stele divided in wedged sections; truncated tips of the wedges terminating in a parenchymatic longitudinally extended space, as a pith constricted at levels. Radial incipient spaces between wedges only discemible near the center of the axis. Along the lenght of the axis typical constrictions in these parenchymatic spaces are seen, as a result of the crossing of the tracheids from one margin to the other margin, and resulting from this feature axial parenchymatic pockets longitudinally settled; in this sense there are not true trusses or platforms between the wedges but, at the level of each constriction adventitious root traces have their beginning. Maturation of the young adventitious roots into the secondary xylem body. Shorter length of the tracheids at each constriction level, resembling the transfusion type of tissue. Initials of xylem wedges not preserved and primary formations as common in roots are absent; growth rings distinct; parenchymatic cells included in the rings Short uniseriate rays; pitting arrangement as evenly separated groups, combining groups of 2 to 6 pits on the radial walls; pits tipically small-sized: $3-4 \mu$. in diameter; combined features resembling those of several modern underground or runner axes, from swamp enviroments and warmer climates; gymnospermic type of wood.

Myelontordoxylon brasiliense $\mathbf{n}$. sp.

(Pl. VII: Figs. 39-45; Pl. VIII: Figs. 46-48)

Holotypus: GP/3T. 111 Depto. Paleontoiggia e Estratigrafia, IG/USP.

Locality: Pedreira Maluf (AF/GP. 80 IR/S.P.) near Piracicaba, State of São Paulo, Brazil.
Age: Permian (Irati Formation)

Description: Surange \& Maheshwari (1962) described a compressed axis of Vertebraria from Raniganj Coalfields in India, as having an indicative impression of a pith; they named that specimen as $V$. myelonis. Our petrified sample has not the external morphological features of Vertebraria. It is cylindrical in its outline, having three elliptical scars, with about $1,5 / 0,8 \mathrm{~cm}$ (P1. VII: Fig. 39) in length; the transversal view of this sample shows clearly demarcated rings from near the center of the axis toward the external margin of it. The center of the sample is diminute and one can suppose there is only a meeting point where the wedges terminate, but under microscope a fairly organized parenchymatic pith can be observed (Pl. VII: Fig. 40). The tips of the wedges as in $M$, vittii are truncated; between the parenchymatic cells of the pith, at the level of the tips of the wedges occur a sheath of thick walled isodiametric elements, which are not typical parenchyma cells and preferably a transfusion tissue. The growth rings clearly present zones of early and late wood (1-3 strands of shorter elements); in some of the rings (P1. VII: Fig. 41) the cambial activity of the parenchyma cells is clear as usually occur in all of the samples; short (1-3 cells high) uniseriated rays, few in number per sq. mm. The radial sections also show the evenly spaced pitting groups, showing described groups with rosette form (Pl. VII: Fig. 44-45). The most significative anatomical event is the appearing of adventitious root primordia, in series of usually three alternate roots at each level, along the lenght of the axis. Hence, these primordia do not appear at any place, but at definite levels, and generally as series of three primordia preferably. This feature lend us to admit a stem nature for the axis, since in stems are common the appearing of adventitious root primordia, related to the nodal levels and directly orinating from pith. Transections of the axis show (Pl. VII: Fig. 39) parenchymatic bands like those of leaf gaps radially extended, and it would be possible the association of these groups of adventitous root-primordial, with the nodal levels, where leaves have their departure. It was observed the occurrence of these groups of roots at the cut level of an 
externally located scar. In (PI. VII: Fig. 42) a waved outline is observed in the xylem elements with respect to the departure of these traces. Pl. VIII (Figs. 46-48) details different stages of maturation of these roots; Figs. 4647 (Pl. VIII) show the young adventitious root bodies in transversal view as well as their tetrach nature; Fig. 48 show a young root with its formed cap, differentiated tissues of the root cylinder and the connecting cells of the vascular systems of the axis and root.

Discussion: Myelontordoxylon brasiliense is closely comparable with Myelontordoxy. lon vittii but it differs in the absence of pith constrictions, along the pith lenght into the axis. $M$. vittii neverthless, when cut at the level of an axial pocket shows a deffined pith and its transversal view, similar to the transversal view of $M$. brasiliense. As comparing the departure of traces in both samples (GP/3T. 111 and GP/3T. 112), M. vittii usually shows one or even two traces passing out from the pith constriction to the woody body, which have an approximately perpendicular course with respect to the length of the axis, while $M$. brasiliense generally shows groups of three traces, whose course is an spire along the length of the axis. As a result this sample was designated as a new species. With regard to the anatomy of the vertebrarian axes described by Schopf (1965) and by Gould (1973) as well as with regard to the anatomy of Tordoxylon (Kräusel, 1956) the discussion of $M$. Vittii is valid concerning $M$. brasiliense.

\section{Myelontordoxylon brasiliense $\mathbf{n}$. $\mathbf{s p}$.} (Holotipus GP/3T. 112; PI. VII: Figs. 39-45;

\section{PI. VIII : Figs. 46-48)}

Diagnosis: Symmetric outline of the vascular cylinder; spaces between the wedges are not visible under naked eyes; the center of the axis is distinct and the pith being discemible only under magnification; parenchymatic pith extended along the length of the axis, with a stellate outline by the intromission of parenchyma cells as leaf gaps between the initials of the wedges. Tips of the wedges truncated being continued by the parenchymatic cells of the pith; between the initials of the wedges and the cells of the pith a sheath of thick walled isodiametric cells like parenchyma represent a transfusion type of tissue. Scarce rays per sq. mm. Short rays (1-2 cells high) 1-seriated. Vascular pits in groups (rosette form) evenly spaced. Longitudinal sections showing tetracch young adventitious roots, having their body about ready to emerge in the axis and with a spiral course through the stem. Gymnospermous wood which may be paralelled to some modern stems living in periodically inundated areas or swamp environments.

\section{Paratordoxylon n. g.}

Diagnosis: Acute terminating wedges closely disposed in transversal views. Incipient spaces between the wedges; pith observed in the major axis, but a pith is seen in the adventitious branch formation, into the major wood cylinder; in the pith of the adventitious branch tracheids were being formed at levels, so that this little pith presents structures which resemble the xylem platforms of Vertebraria.

Sample: GP/3T. 114 and GP/3T. 114. Depto. Paleontologia e Estratigrafia, IG/USP.

Locality: Pedreira Maluf (AF/GP 80. IR/S.P.) near Piracicaba, São Paulo, Brazil. Age: Permian (Irati Formation).

Paratordoxylon camposi n. g., n. sp. (Holotypus: GP/3T. 114: PI. VIII-XI: Figs. 49-64)

Description: A number of significant questions will be posed in the discription of this sample as a result of the peculiar pattern in the vascular cylinder. Future developmental studies will be need to reach a better understanding concerned the anatomical features inherent these fossilized axes; with regard to their asymmetric outline as well as the lack of primary formations as typical in roots they may be paralleled to Tordoxy. lon. Pl. VIII: Fig. 51 shows the sample cut at several levels, from one extreme to the other. One of these cuts was empoloyed to make petrographic sections and the other cuts were dealt with peel thin sections. P1. 


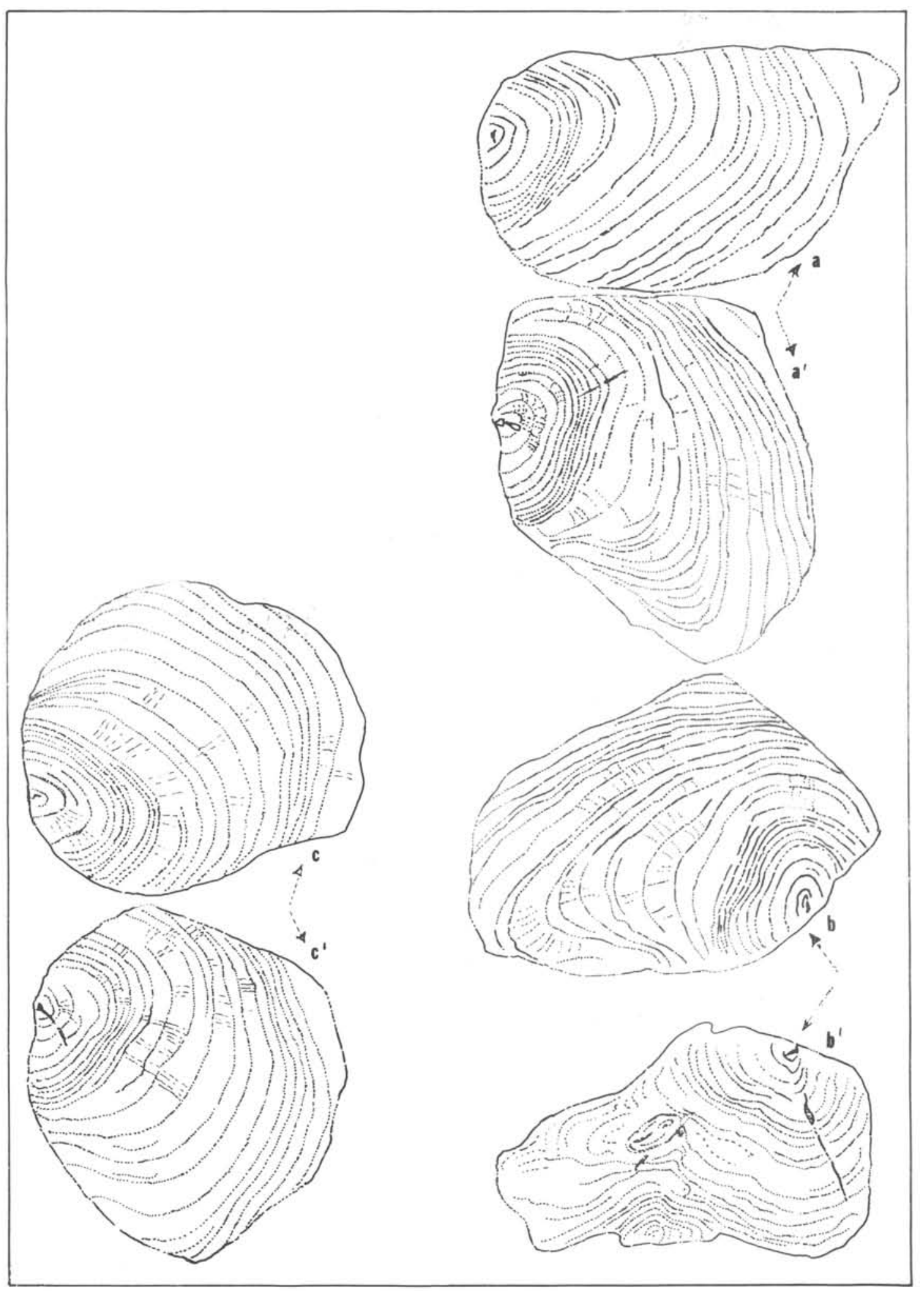

FIG. 6

Diagramatic drawing showing serial asymmetric transversal sections in PARATORDOXYLON $\mathrm{n}, \mathrm{g}$. 
IX: Fig. 52 correspond to a field in this level and one can see acute terminating wedges closely disposed each other. The other levels only show incipient spaces between the wedges; at level 3 two aliform spaces were already formed (Pl. IX: Fig. 53). The tips of the wedges as shown are acute along the length of the axis and this is an inherent feature. No primary structures concerning the core of roots could be seen, but only scattered cells of parenchyma filling the small central space. At level 5 (Pl. VIII: Fig. 49) one can observe a waving disturb in the rings (TextFig. 6) and from level 4 to 6 it is seen a median furrow in the rings which changes their general outline. This disturbance is related to an issuing trace (Pl. IX: Fig. 54) that may represent a single root-trace or even a leaf trace, which run to the leaf; imediately below the level where this single trace appears a new structure is formed (level 5) as seen in Pl. VIII (Fig. 49) and Pl. X (Figs. 56, 57). At one point in the furrow the cambial activity or the parenchyma cells of the ring and ray cells provide elements to form a complete structure, like a little stele of an adventitious root or branch. Usually branch traces appear in cross-sections as inclined bundles running to the outermost sheats of the organ. In here these bundles are organized as an entire little unity into the major one, with their rays and tracheids tangentially seen in cross-section. The vascular elements of this smaller vascular unit delimit a young parenchynatic pith, which could be observed along its entire length (P1. X: Figs. 58, 59). Above and below this young stele some parenchymatic gaps occur in the major axis, as providing new formed elements to the smaller stele (Pl. X: Fig. 57). Whorls of vascular tissue in the major axis indicate that those are connecting structures (PI. XI: Fig. 62) between the major axis and the minor stelic unit. The young pith in the smaller stele as observed under high magnification showed a quite significant pattern (P1. XI: Figs. 61, 63, 64), since at different levels the pith parenchyma generates transversal vascular neo-formed elements; the resulting configuration resemble several immature platforms, paralleled to those mentioned in the mature axes of the vertebrarian complex. Around the adventitious unit the waving rings are turned to the outer margin of the cylinder and the adventitious stele seems to be almost ready to leave the mother axis as an independent cylinder.

Discussion: Although showing affinities with the genus Tordoxylon this sample assembles a number of original features that recommended its classification in an independent genus named Paratordoxylon n. g. The combined features of the sample may be concerned to the basal portion of a stem with adventitious roots, or (propable alternative) it may be concerned to an anomalous type of stem or liana in which the asymmetric outline is a constant. It may be demonstrated in the future why the persistent lack of primary formations as common in roots is a constant in these types of axes and so, they will have a better understanding than now, as a feature; in these samples the vascular pitting arrengement is similar to the genus Tordoxylon and to the genus Myelontordoxylon concerning late wood; in earlier wood occur an araucarian type of pit-organization on the walls of the tracheids.

Paratordoxylon camposi n. g., n. sp.*

(Holotypus: GP/3T. 113; Pls. VIII - XI:

Figs. 49-64)

Diagnosis: Gymnospermous wood; asymmetric outline; remains of a forked branch at one end. Waving growth rings clearly seen from near tips of the wedges to the peryphery of the cylinder; a stress in the waving of the rings at the levels of traces and branch departure. Acute typs of closely spaced wedges; incipient spaces between the wedges; not visible pith in the major axis; at the level of the branching a neo-formed structure like an adventitious stele shows a parenchymatic pith; this is interupted at levels by some neo-formed transversal vascular elements, resembling a girdle or an immature platform, as seen in the mature axes of the complex Vertebraria. A single trace above the level of the adventitious branching with scalariform and spiral tracheids. At the level of the forked structure adventitious unit is formed into the mother axis as a cilinder almost ready to emerge on the periphery of the axis; whorls of vascular elements in the major axis indicate

* The species is dedicated to Prof. Dr. A. C. Rocha Campos, head of Depto. Paleontologia e Estratigrafia, IG-USP. 
that these unities are interconnected in origin; late wood showing groups of pits (rosette form) and early wood showing an araucarian type of arrangement.

\section{CONCLUSIONS}

The anatomical pattern of these axes strongly resembles that of plants living in swamp conditions, or in places periodically inundated, even in litoral conditions or at places where seasonal raining usually occur. The persistent lack of primary structures as usually recognized in roots is a constant; although in roots these structures may be altered during secondary growth, generally occur in them different type of organization concerning the vascular elements, which leave their remains to be observed later. Thus, the lack of a primary core brings about implications in the recognition of several of these samples as stems. Future developmental studies will be need to better understand the complexity of these axes showing affinities with the Vertebraria axes within a vertebrarian complex.

The samples described in this work seem to have been fossiliz ${ }^{-1}$ at the same type of enviroment as where they lived; preferably they fossilized during deposition of the Irati Formation; their anatomical features are in agreement with the warmer climates and the environmental conditions where Irati Formation were deposited.

The frequency of wood samples having adventitious root traces at this level of the exploring calcerous quarries near Piracicaba indicates a faciologic variation if compared wich the first wood samples studied in the same Formation.

\section{BIBLIOGRAPHY}

AMARAL, S. E. A. - 1971 - Geologia e Petrologia da Formação Irati (Permiano) no Estado de São Paulo. Bol. n? 2, IG/USP.

ARBER, E. A. N. - 1902 - On the Clarke Collection of Fossil Plants from New South Wales. Quart. J. Geol. Soc. 58:1-26.

BAKSHI, T. S. \& COMPLAND, R. T. - 1939 - An Anatomical Study of the Subterranean Organs of Euphorbia esula in Relation to its Control. Can. J. Botany $37: 613-616,1 \mathrm{Pl}$.

BOREAU, E. - 1954 - Anatomie Vegetale: V. I: L' Appareil Végétative des Phanérogames. Press. Universit. de France, Paris.

BUNBURY, C. J. F. - 1861 - Notes on a Collection of Fossil Plants from Nagpur, Central India. Quart. J. Geol. Soc., $17: 325-346$.

CARLSON, M. C. - 1938 - The Formation of Nodal Adventitious Roots in Salix cordata. Am. Journ. Bot. $25: 721-725$.

CARLSON, M. C. - 1950 - Nodal Adventitious Roots in Willow Stems of Different Ages. Am. Journ. Bot. $37: 555-561$.

CLARK, W. A. - 1933 - Vegetative Propagation in Cotoneaster. Trans. and Proc. Bot. Soc. Edinburgh $31(2): 256-261$.

DAEMON, R. F. \& QUADROS, L. P. - 1970 - Bioestratigrafia do Neopaleozóico da Bacia do Paraná, Anais do XXIV Congresso Brasileiro de Geologia, Soc. Bras. Geol., Brasília, 1970 : 359-412.

DANA, J. D. - 1849 - Wilkes, United States Exploring Expedition, Geology (10), New York. 
DOLIANITI, E. - 1954 - A Flora do Gondwana Inferior em Sta. Catarina. 4. O gênero Vertebraria. Notas Prelm. Estudos, 81. DGM, DNPM, Rio de Janeiro, Brasil.

ESAU, K. - 1953 - Plant Anatomy, N. York, John Wiley \& Sons. $6^{\text {th }}$ ed.

FAHN, A. - 1964 - Plant Anatomy, N. York, John Wiley \& Sons. $1^{\text {st }}$ ed.

FEISTMANTEL, O. - 1882 - The Fossil Flora of the Gondwana System. The Fossil Flora of the South Rewah Gondwana Basin-Palaeontologia Indica Mem. Geol. Surv. India. Ser. 12 (4) : 1-52.

FEISTMANTEL, O. - 1886 - The fossil Flora of the Gondwana System. The Fossil Flora of Some of the Coalfields in Western Bengal. Palaeontologia Indica. Mem. Geol. Surv. India, Ser. 12(4:2) :1-66.

FÛLFARO, V. J. - 1971 - A Evolução Tectônica e Paleogeográfica da Bacia Sedimentar do Paraná pelo "Trend Surface Analysis”. Esc. de Eng. de São Carlos, Universidade de São Paulo, Brasil. Geologia no 14.

GOULD, R. E. - 1973 - A Preliminary Report on Petrified Axes of Vertebraria From the Permian of Eastern Australia. Gondwana Geology K. S. Campbell Editor Austral. Nat. Univ. Press.

KRÄUSEL, R. - 1956 - Ergebnisse der Forschungsreise... 2. Lianen aus den Karru-Schicten Süd Afrikas. Seckenberg.

KRÄUSEL, R. \& DOLIANITI - 1958 - Gymnospermenholzer aus dem Palaozoikum Braziliens. Palaeontographica 104. B (4-6):115-137. Stuttgart.

MARGUERIER, J. - 1973 - Paleoxylogie du Gondwana Africain: Étude et Affinités Du Genre Australoxylon. Palaeontologie Afr., $16: 37-58$.

MASDEN, M. P. F. \& STEeVES, T. A. - 1955 - On the Primary Vascular System and the Nodal Anatomy of Ephedra. Arnold Arboretum Jour. $36: 241-258$.

MENDES, J. C.; FÜLFARO, V. J., S. E. \& LANDIM, P. M. B. - 1966 - A Formação Irati (Permiano) e Fácies Associadas. Bol. Soc. Bras. Geol., n? 15 (3), São Paulo.

MORRISON, T. M. - 1953 - Comparative Histology of Secondary xylem in Buried and Exposed Roots of Dicotiledonous Trees. Phytomorphology $3: 427-430$.

OLDHAM, R. D. - 1897 - On a Plant of Glossopteris With Part of the Rhizome Attached and on the Structure of Vertebraria. Rec. Geol. Surv. India $30: 45-50$.

PAINT, D. D. - 1956 - On two Compressed Palaeozoic Axes. Ann. Bot. (N. S.) 20 :419-429.

PANT, D. D. - 1967 - On the Stem and Attachment of Glossopteris leaves. Phytomorphology 17 (1-4) :351-359.

PANT, D. D. \& SINGH, R. S. - 1968 - The Structure of Vertebraria indica Royle. Palaeontology, 11 (5) :643-653.

PANT, D. D. \& SINGH, R. S. - 1974 - On the Stem and Attachment of Glossopteris and Gangamopteris Leaves. Part II Structural Features. Palaeontographica Abt. B. 147 (1-3) : 42-73. Pl. 23-35.

PLUMSTEAD, E. P. - 1958 - The Habit of Growth of Glossopteridae. Trans. Geol. Soc. S. Afr. (61) : 81-94.

PLUMSTEAD, E. P. - 1962 - Fossil Floras of Antarctica. T. A. E. Scientific Reports $9: 57-61$.

SCHOPF, J. M. - 1965 - Anatomy of the Axis in Vertebraria. Geol. and Palaeont. of the Antarctic. Antarctic Res. Ser. 6. Amer. Geopl ys. Union: 217-228.

SEN, J. - 1955 - Structure of Vertebraria. Nature Lond. 175-176.

SEN, J. - 1958 - Further Studies on the Structure of Vertebraria. Bot. Notiser $111: 436-448$.

SEWARD, A. C. \& WALTON, J. - 1923 - On a Collection of Fossil Plants from the Falkland Islands, Geol. Soc. London Quart. J. 79 pt. 3 (13) : 313-333. 
EWARD, A. C. - 1914 - British Antarctic ("Terra Nova") Expedition, 1910. Antarctic Fossil Plants. Geol. 1 (1) : $1-49$.

MITH, A. I. - 1936 - Adventitious Roots in Stem Cuttings of Begonia maculata and B. semperflorens. Am. Jour. Bot. 23:511-515.

URANGE \& MAHESHWARI - 1962 - Studies in the Glossopteris Flora of India. 11. Some Observations on Vertebraria from the Lower Gondwanas of India. Palaeobotanist $9: 61-67$.

AYLOR, G. - 1926 - The Origin of Adventitiou Growth in Acanthus Montanus. Trans. and Proc. Bot. Soc. Endinburg 29 (3) : 291-296.

'ALTON, J. \& WILSON, J. R. - 1932 - On the Structure of Vertebraria. Proc. R. Soc. Edinb. 52 : 200-207.

EILLER, R. - 1896 - Étude Sur Quelques Plantes Fossiles en Particulier Vertebraria et Glossopteris des Environs de Jahannesburg (Transvaal). Bull. Soc. Géol. Fr. 24 :349-378. 
PLATE I

Tordoxilon sanpaulense n. s. p.

Fig. 1: Transverse section showing the asymmetric growth of the vascular cylinder resulting from different growth increment in each wedge. Wavy growth rings are seen as well as spaces between the wedges. $\times 1,6(\mathrm{GP} / 3 \mathrm{~T}$. 109).

Fig. 2: Radial section showing pits on tracheid walls. $X 250$. (GP/3T. 109).

Fig. 3: Sample shown at natural size; small scars are seen in an alternate arrangement. Text-Fig. 4 is based on this sample. (GP/3T. 109).

Fig. 4: Samples embedded in the calcerous rock matrix (GP/3T. 109 and GP/3T. 110).

Fig. 5: Transverse section, showing curved and well preserved tips of the wedges. They begin in anunmassive core which communicates with the radial spaces between wedges. X 5,0 (GP/3T. 109). 
PLATE I
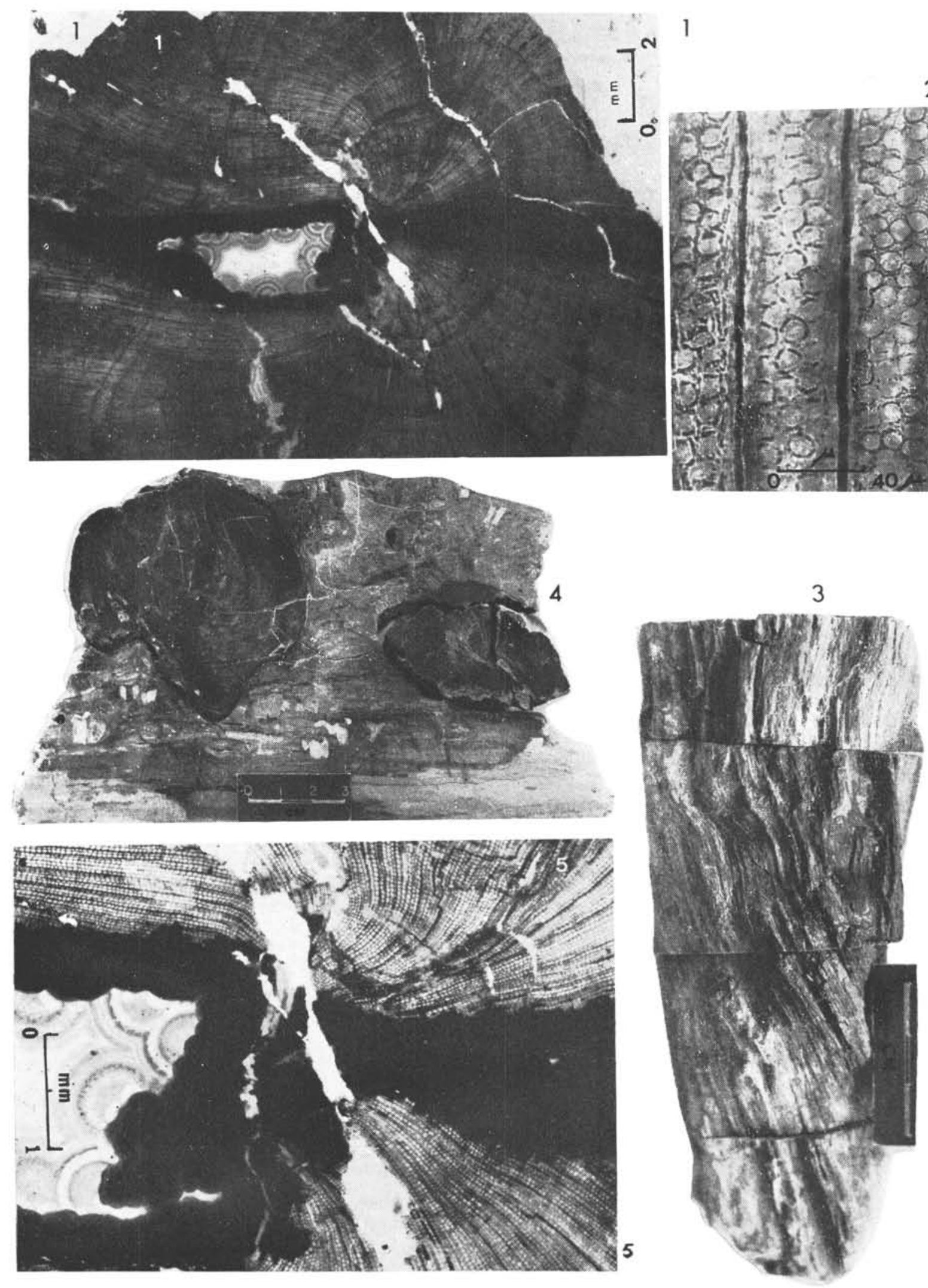
PLATE ॥

Tordoxilon sanpaulense n. s. p.

Fig. 6: Tangential view showing a node in the secondary wood. $\times 4,0$ (GP/3T. 109).

Fig. 7: Tangential view: another node cut longitudinally. The vascular bundle is centrally located. X 6,4 (GP/3T. 109).

Figs. 8-9: Details of the vascular bundles of the node shown in Fig. $6 . X 25$ (Fig. 8); X 25 (Fig. 9); X 100 (Fig. 10). (GP/3T. 109).

Fig. 10: Tangential section: young adventitious root-trace passing out through the wood body. X 2,5 (GP/3T. 109). 

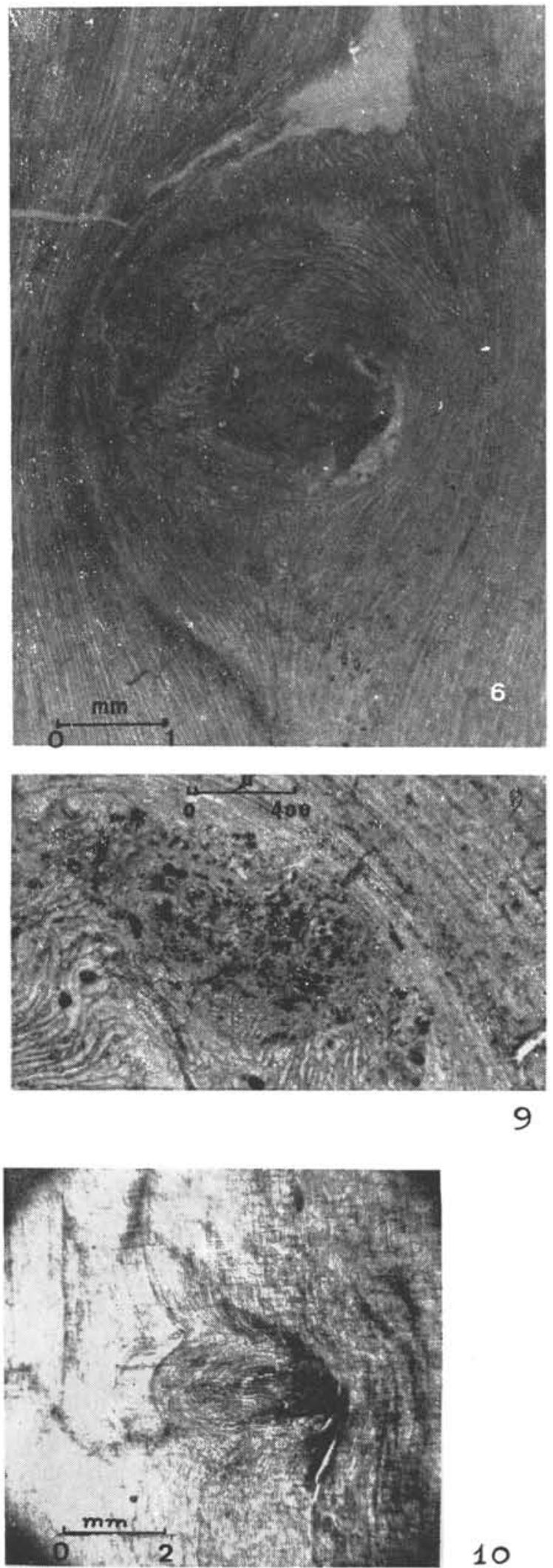

10
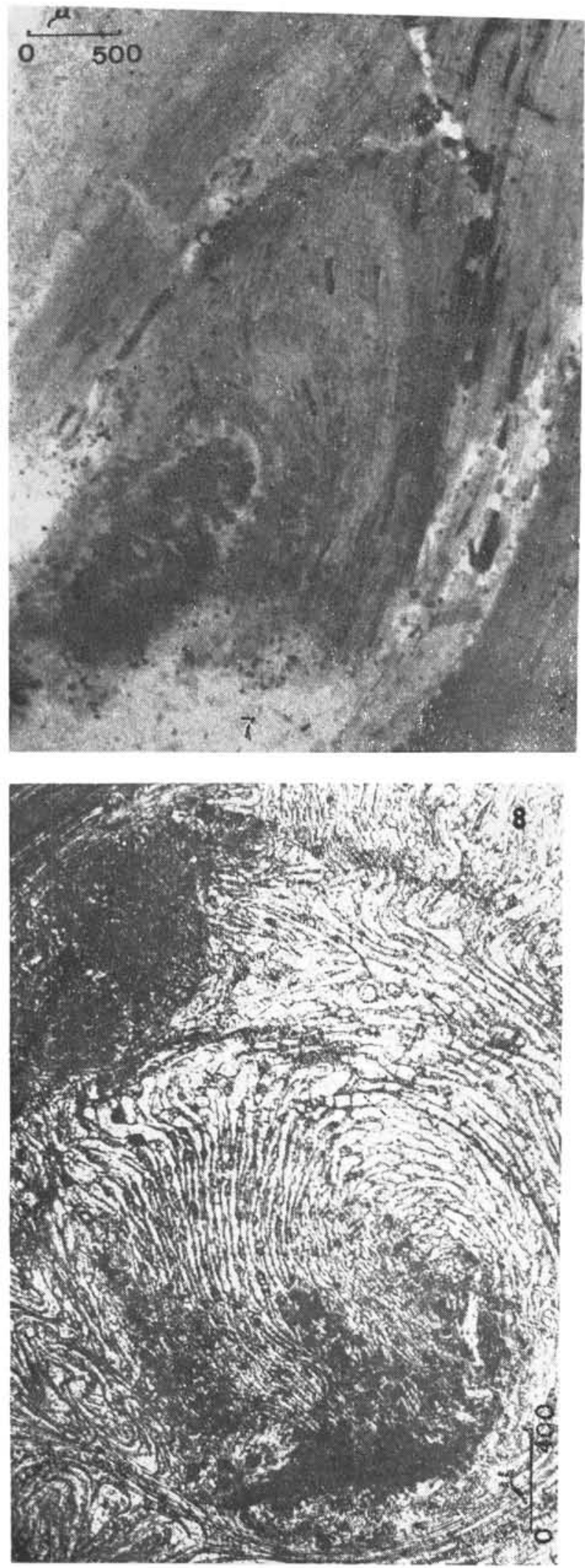
PLATE III

Tordoxylon sampaulense n. sp.

11: Surface view of sample B of Fig. 4 (PI. I): wavy growth rings; acutely terminared wedges with well-preserved tips closely resembling those in Tordoxylon steinspruitense from South Africa. X 3,2 (GP/3T. 110).

g. 12: Longitudinal view throught the spaces between the wedges. There are several vestigial structures at levels, which may represent a transfusion tissue which was ruptured when the traces had departed theoughout the wood. In the margin of the wood at the same level a node generally is formed. $X 1,6$ (GP/eT. 110).

ig. 13: Detais of the node shown in Fig. 12. X 14 (GP/3T. 110).

=ig. 14: Detail of the residual structures illustrated in Fig. 12. X 6,4 (GP/3T. 110).

Fig. 15: Radial section: pitting groups with a rosette form. $X 250$. (GP/3T. 110).

Fig. 16: Radial section: tracheid combining spiral thickening with bordered pits in a single row, as occurs in Gymnosperm growyh rings, the late wood acquiring the features of a compression wood by the torsion of the axis. $X 250$.

Fig. 17: Cross-fields showing grain-shaped pores, different from "oculipores". $\times 250$ (GP/3T. 110). 


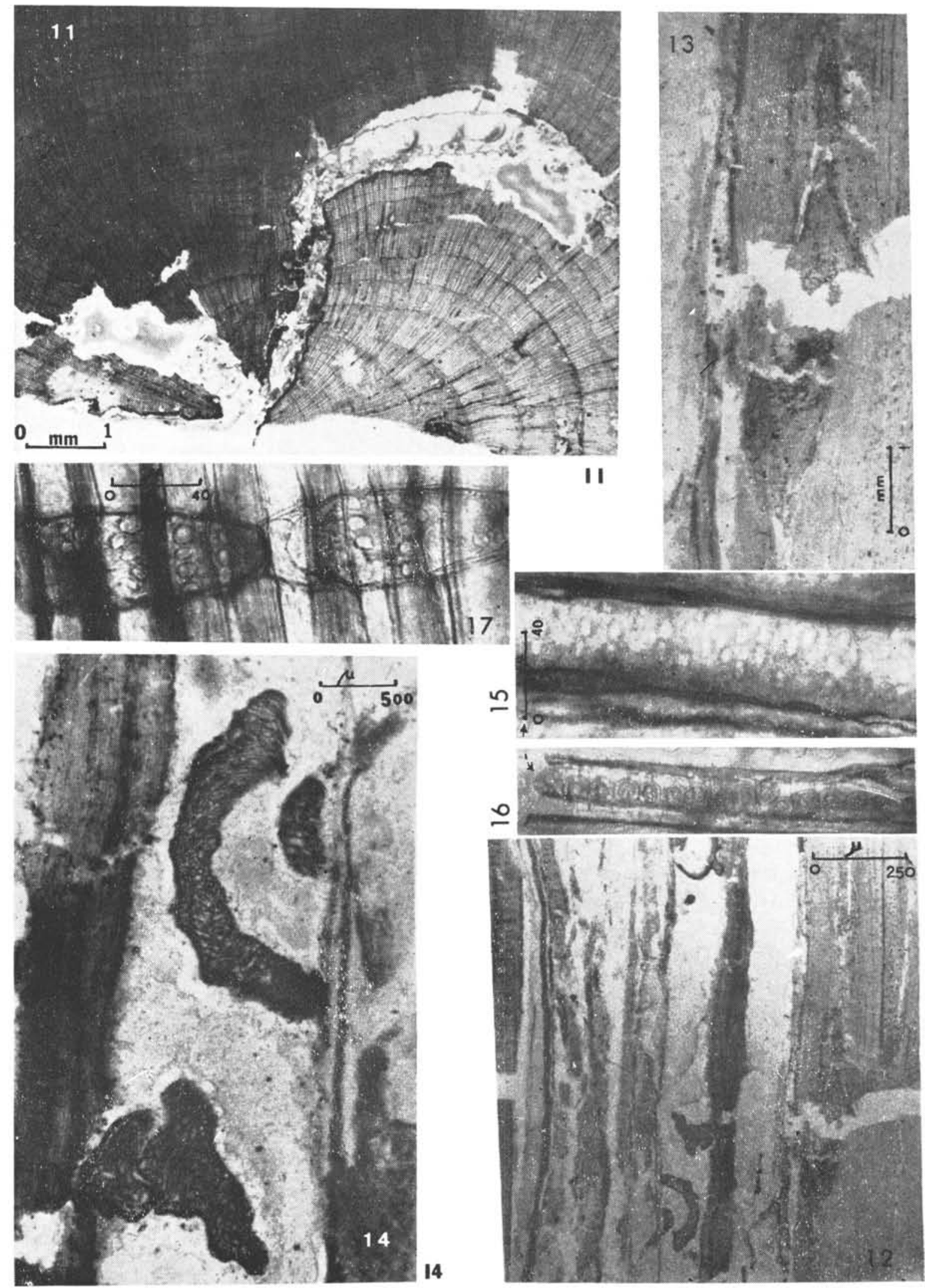




\section{PLATE IV}

Myelontordoxylon vittii n.g., n. sp.

Fig. 18: Transverse section of the center of the axis: the tips of the two wedges are truncated and continued by parenchyma cells filling the gaps. X 100. (GP/3T. 111).

Fig. 19: Transverse section: growth rings clearly defined; included parenchyma cells in them X 160. (GP/3T. 111).

Fig. 20: Surface view of sample GP/3T. 111; Incipient gaps occur between the wedges. $X 0,8$.

Fig. 21: Axial longitudinal section showing a constriction in the central parenchymatic gap caused by the tracheids crossing from one margin of the gap, on the right, to the other margin of the gap, on the left; at this point a new structure is emerging: the trace of an adventitious root. $\times 3,2$ (GP/3T. 111).

Fig. 22: Detais of Fig. 21 showing pentarch root trace. $X 18$ (GP/3T. 111).

Fig. 23: Adventitious root-trace serially sectioned: b) this stage of growth the root is passing $(a, b) \quad$ out through the secondary xylem of the stem, but is still near the central gap. $\times 2,5$ (GP/3T. 111). 


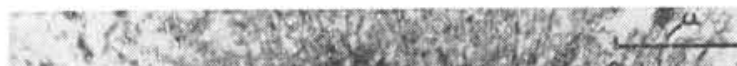

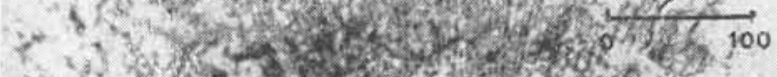
at a a

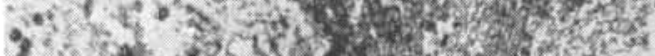

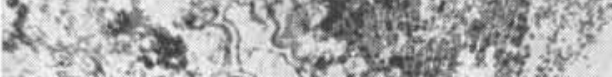

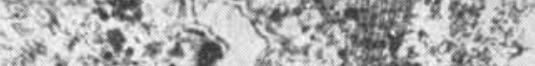

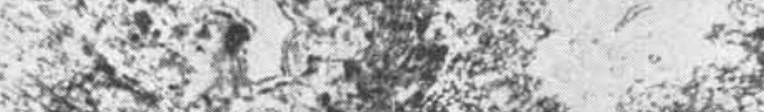

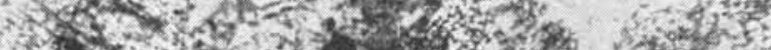

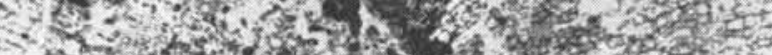

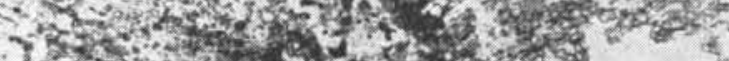

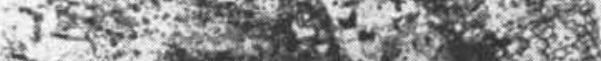

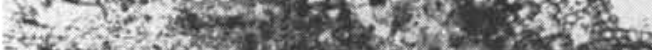

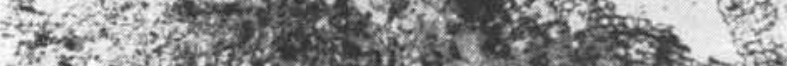

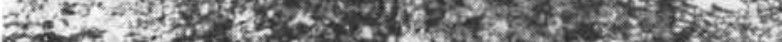

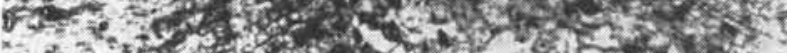

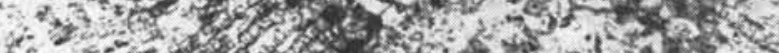

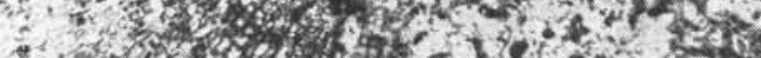

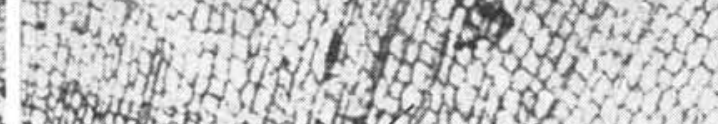

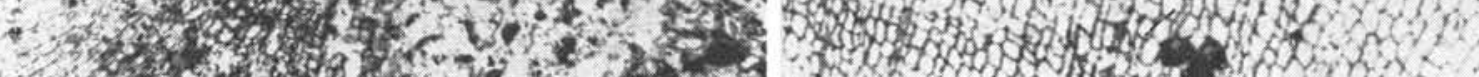

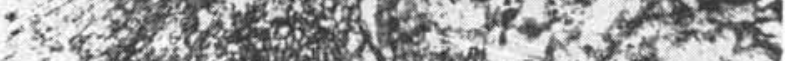

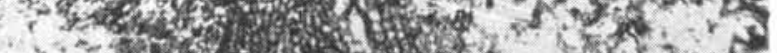

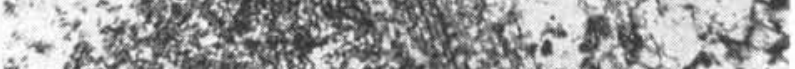

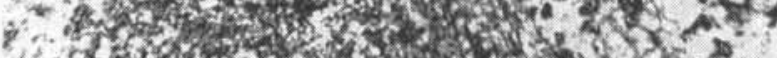

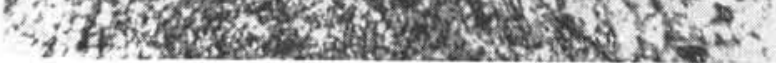
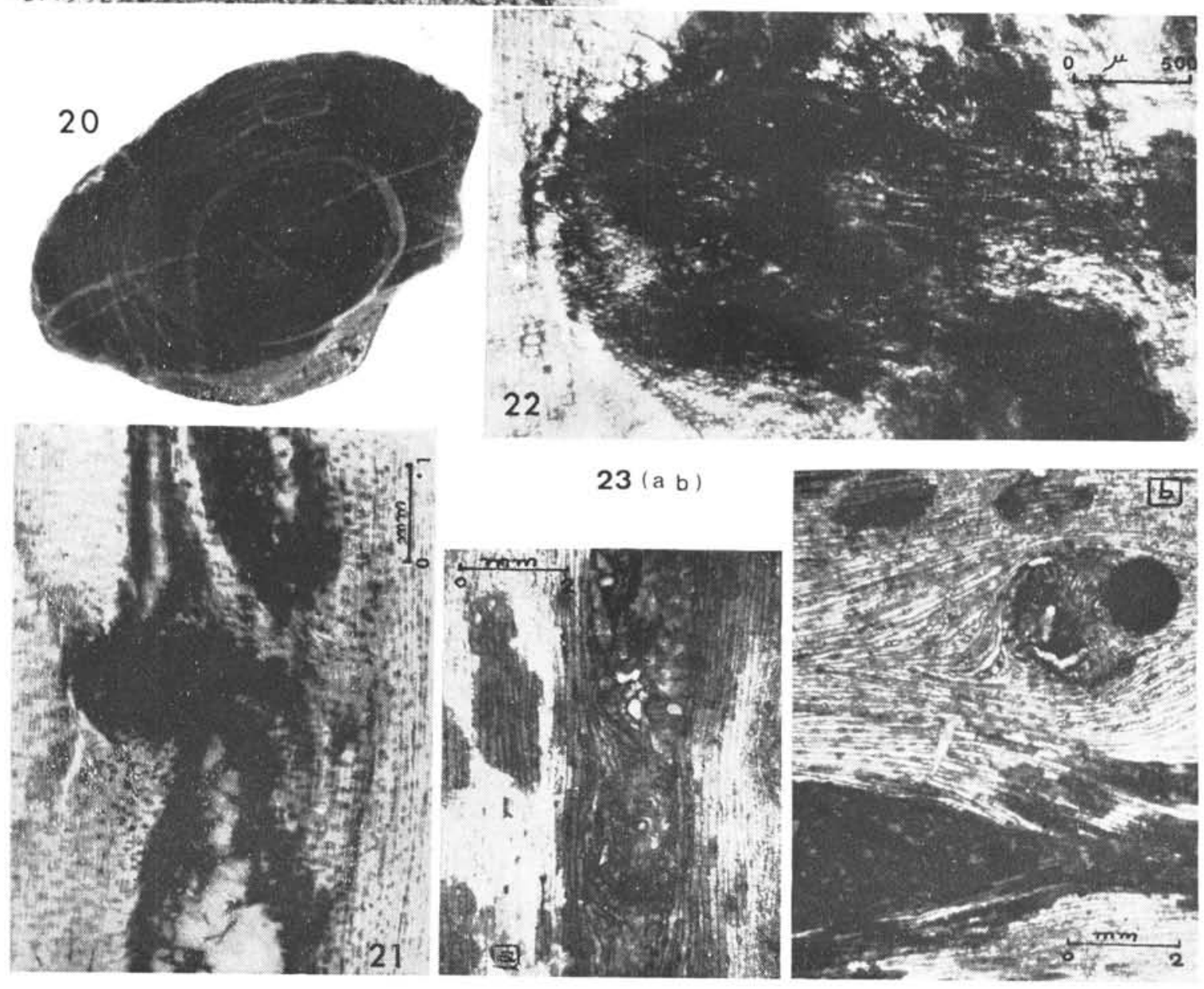


\section{PLATE $V$}

Myelontordoxylon vittii n. g., n. sp.

Figs. 24-25:Adventitious root serially sectioned: a mature stage of growth is seen in the root which shows its definite root cap and maturing tracheids. Vascular elements connecting the young root system and the axis can be seen. X6,4 (Fig. 24); $X 25$ (Fig. 25).

Figs. 26-29:Two emerging adventitious root-traces near a pith constriction. The pith is now subdivided into axial parenchymatic pockets. Fig. 26: early stage of formation (X 3,2): Fig. 27: separation between the two traces is initiated (X 4,0). Fig. 29: the separated traces are passing out through the xylem body (X 25); Fig. 28: the same: an advanced maturing phase $(X 12,8)$. 

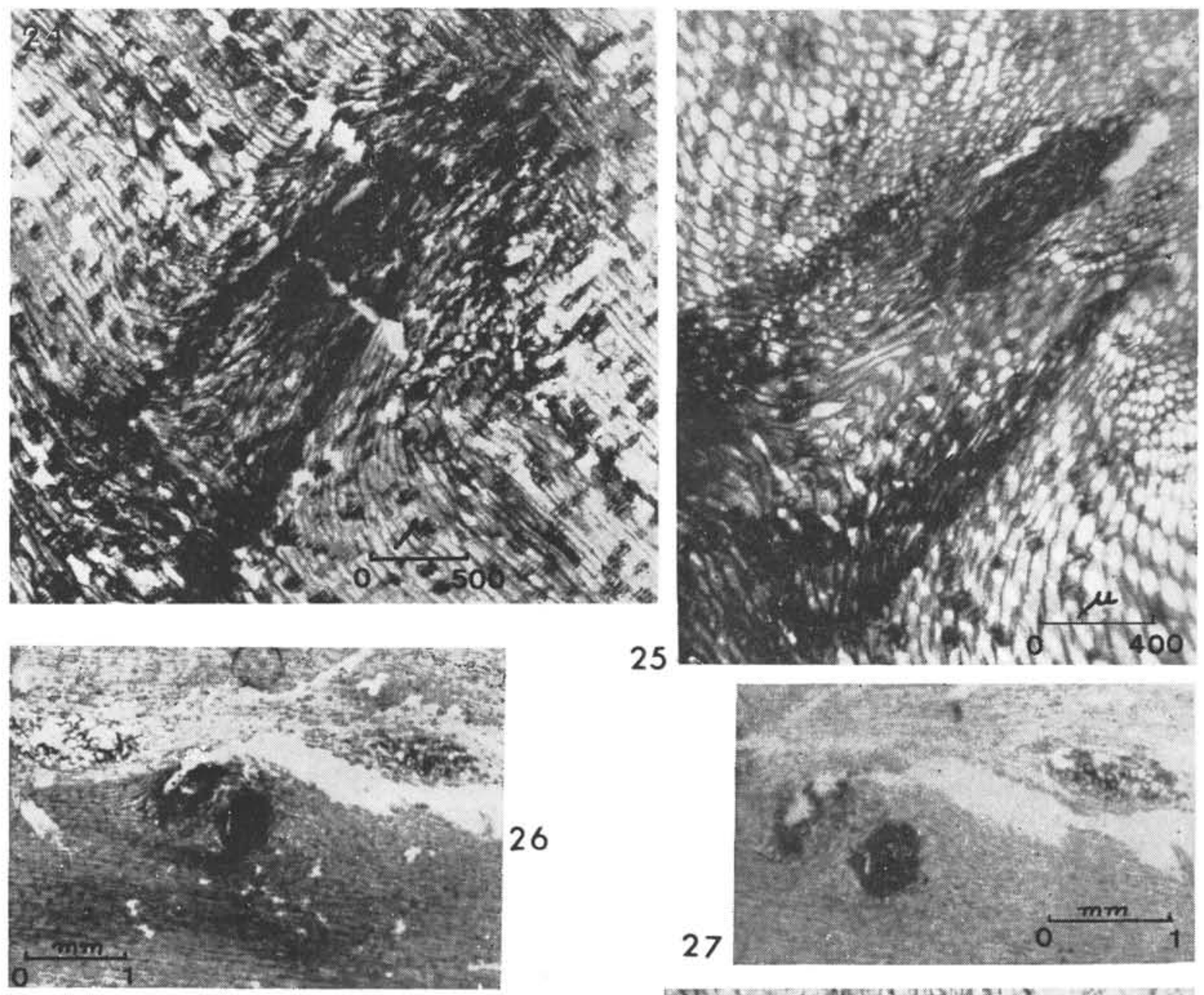

\section{5}
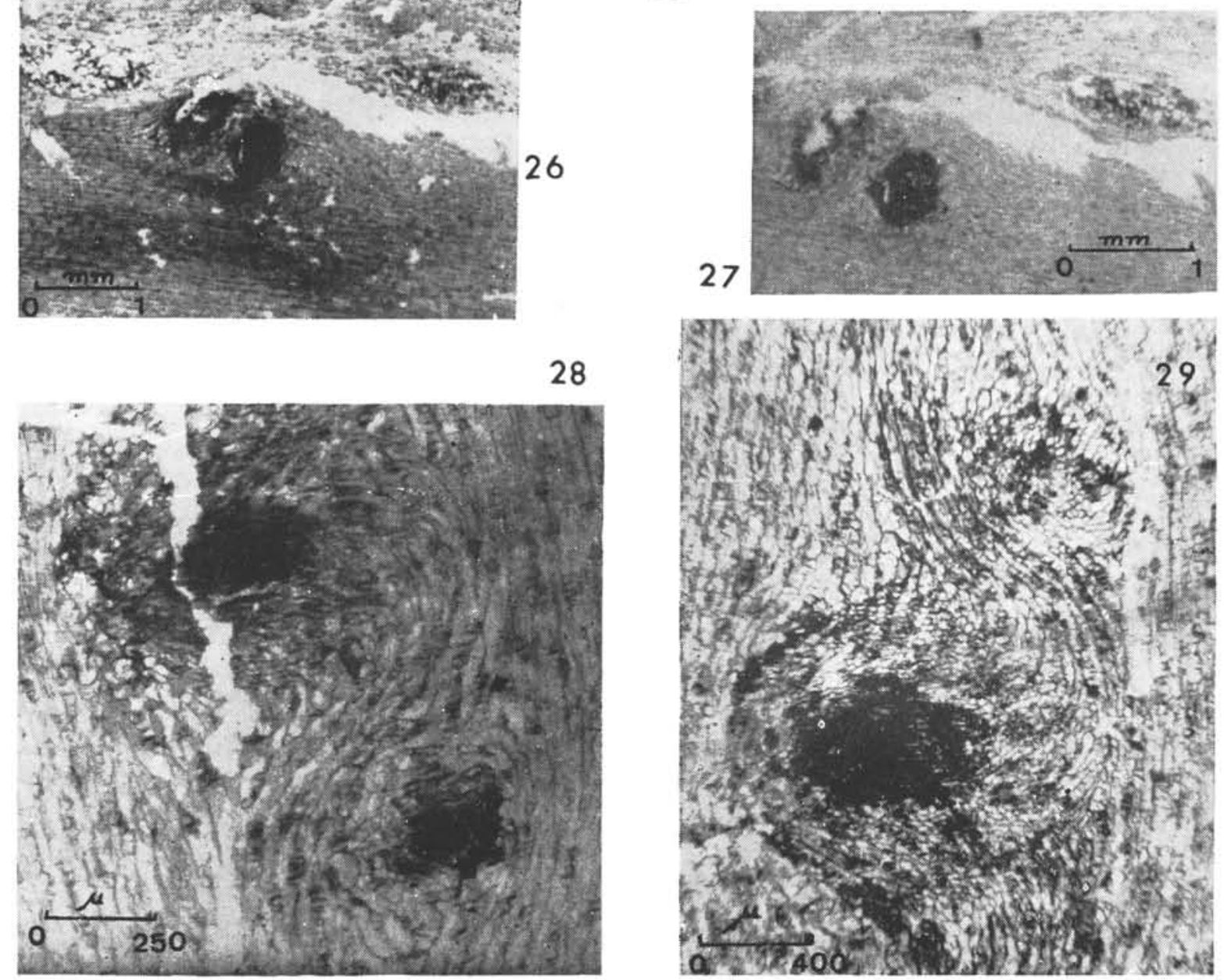


\section{PLATE VI}

Myelontordoxylon vittii n. g., N. sp.

Figs. 30-35; 36: Rosette-shaped groups or stellate groups of pits as a common type of arrangement on the radial walls of the tracheids; there also occur, irregular, vertically separated pit-rows as well as transverse rows of 2-6 groups of pits $X 400$ (GP/3T. 111).

Fig. 34: Cross-fields showing groups of pores varied in shape as grain-shaped pores. These pores are not typical araucarian "oculipores". Lower on the right, a pitting group in the field (rosette form). X 400 (GP/3T. 111).

Fig. 37: Tangential section showing short, uniseriate rays, a common feature in these samples. X 250 (GP/3T. 111).

Fig. 38: Tordoxylon sanpaulense: Tangential section showing a longitudinally extended space having residual structures like ruptured platforms. $X 6,4$ (GP/3T. 110). 
PLATE VI
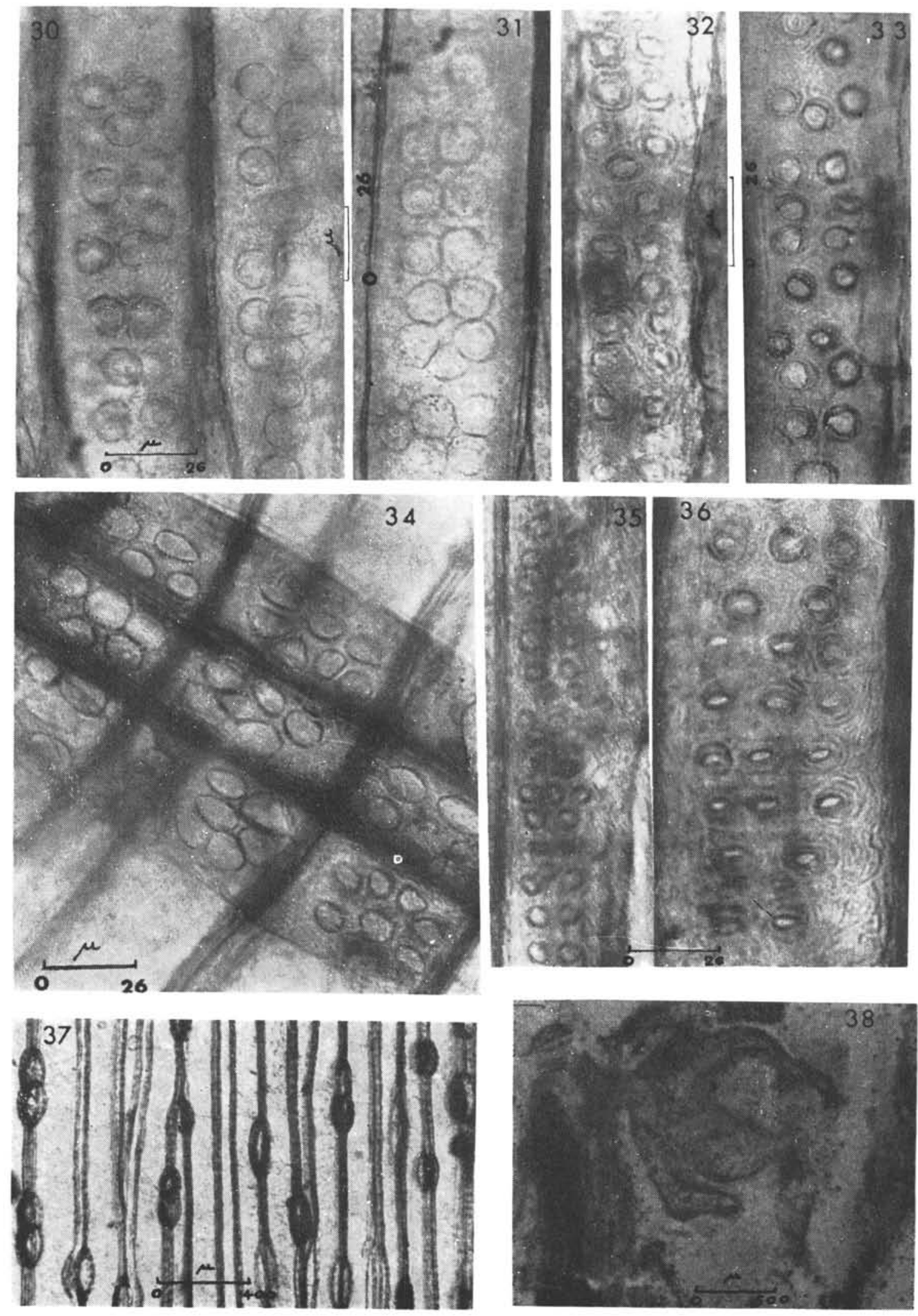


\section{PLATE VII}

\section{Myelontordoxylon brasiliense $\mathrm{n}$. sp.}

Fig. 39: Surface view of the sample. Observe that the incipient pith is only perceivable under magnification (GP/3T. 112).

Fig. 40: Transverse section showing closely wedges spaced and having truncated tips. There is a central parenchymatic pith and the major wedges are separated by parenchymatic gaps. $\times 12,8(G P / 3 T .112)$.

Fig. 41: Transversal section showing included parenchyma cells in the rings. $X 100$ (GP/3T. 112).

Fig. 42: Longitudinal section showing three adventitious root traces at the level of an externally visible node. They are about to emerge through the woody axis. $X 3,2$ (GP/3T. 112).

Fig. 43: Tangential section: uniseriate rays as a common features. $X 100$ (GP/3T. 112).

Figs. 44-45: Radial section, showing the typical pit arrangement, in rosette groups on the radial walls of the tracheids. $\times 40$ (GP/3T. 112). 


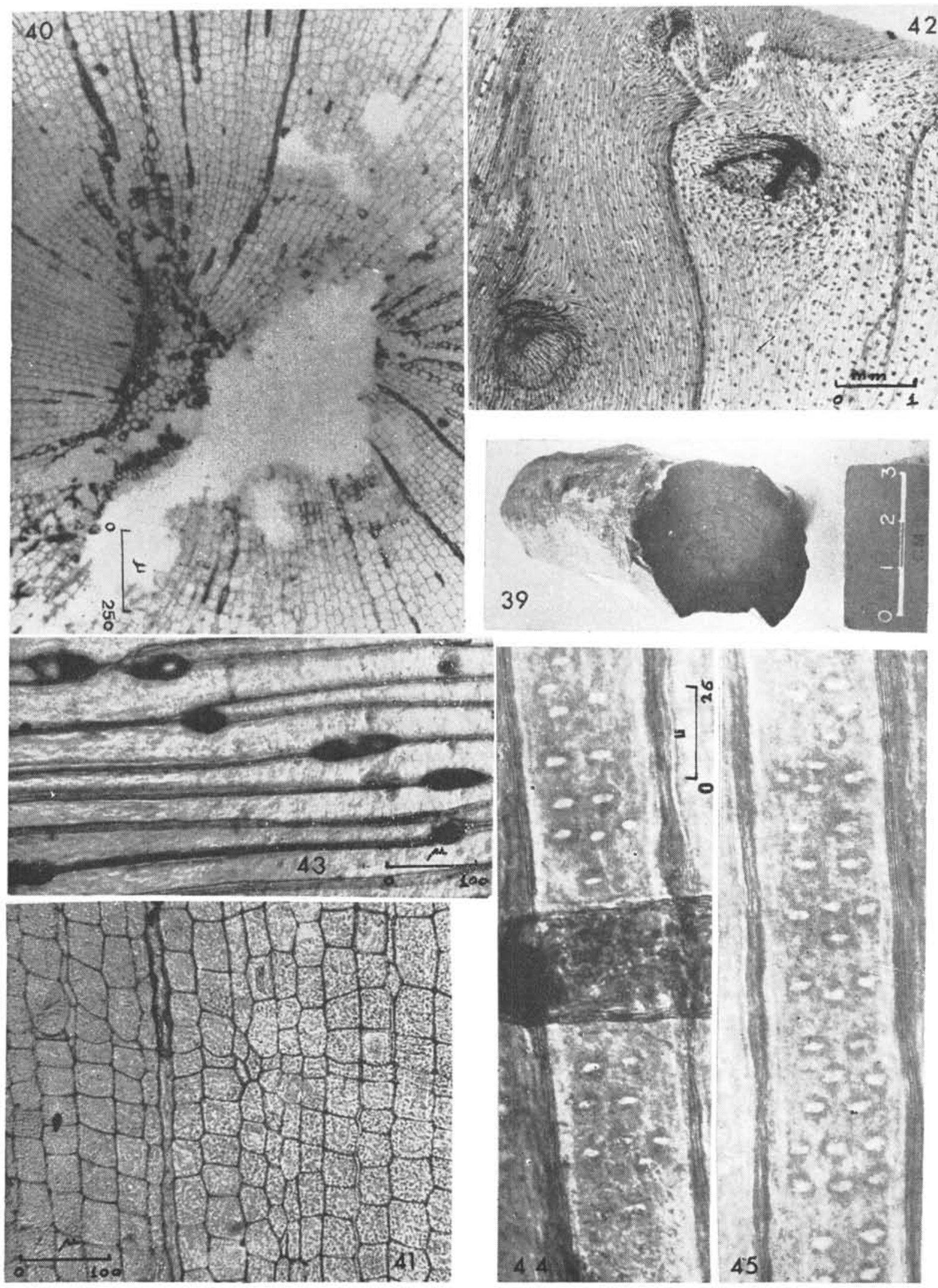




\section{PLATE VIII}

Myelontordoxylon brasiliense $\mathrm{n}$. sp.

Figs. 46-48:Detail of aventitious root shown in Fig. 42. Figs. $46-47$ show the well-formed root body with its pentarch protoxylem arms and differentiated histogens. Fig. 48 shows the roct cap and maturing tracheids about ready to emerge. X 25 (GP/3T. 112).

\section{Paratordoxylon camposi n. g., n. sp.}

Fig. 49: Surface view of section 5 (in Fig. 51) showing the small new-formed stele in the woody body, as an adventitious root or a branch: natural size. (GP/3T. 113).

Fig. 50: Pit arrangement in the earlier tracheids of a ring showing an araucarioid type of arrangement. X 400 (GP/3T. 113).

Fig. 51: Sample showing sucessive sections through the axis. Observe the forked branching at one end of the sample, on the right. (GP/3T. 113). 

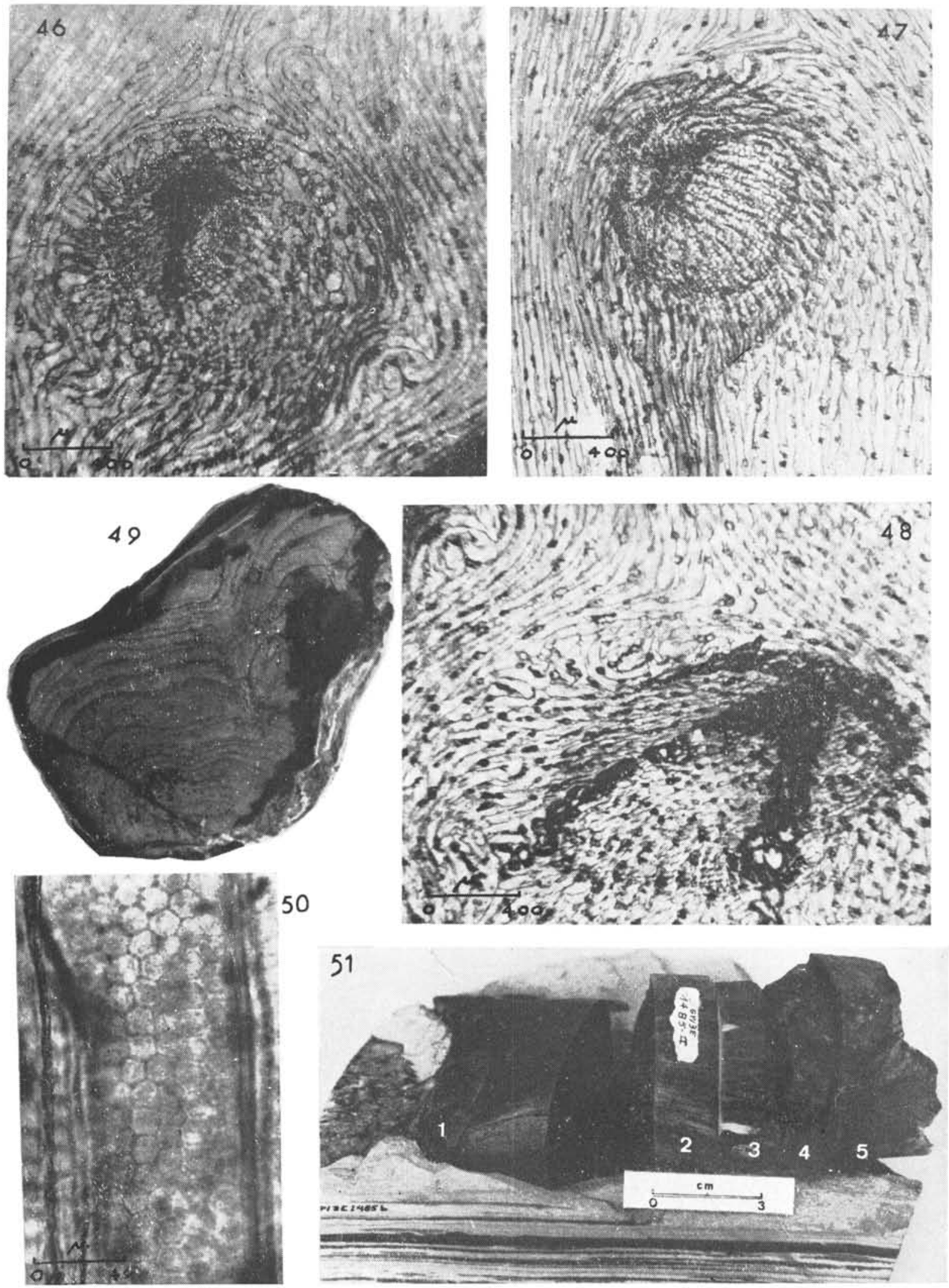

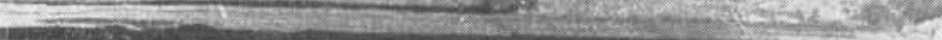


PLATE IX

Paratordoxylon camposi n. g., n. sp.

Fig. 52: Transversal section at level 1 (see Fig. 51) showing acute tips of wedges in an asymmetric axis. Growth rings well formed; wedges closely spaced: incipient parenchimatic gaps. $\times 5,0$.

Fig. 53: Transversal section at level 4 (see Fig. 51) showing parenchymatic radial gaps closely spaced and four acute tips of wedges. X 100 (GP/3T. 113).

Fig. 54: Transversal section at level 4 (see Fig. 51) showing a trace running toward the periphery of the axis. $\times 25$.

Fig. 55: Parenchymatic gaps in the woody body; parenchyma cells seem to have originated by cambial activity in the ray. $\times 250$. 

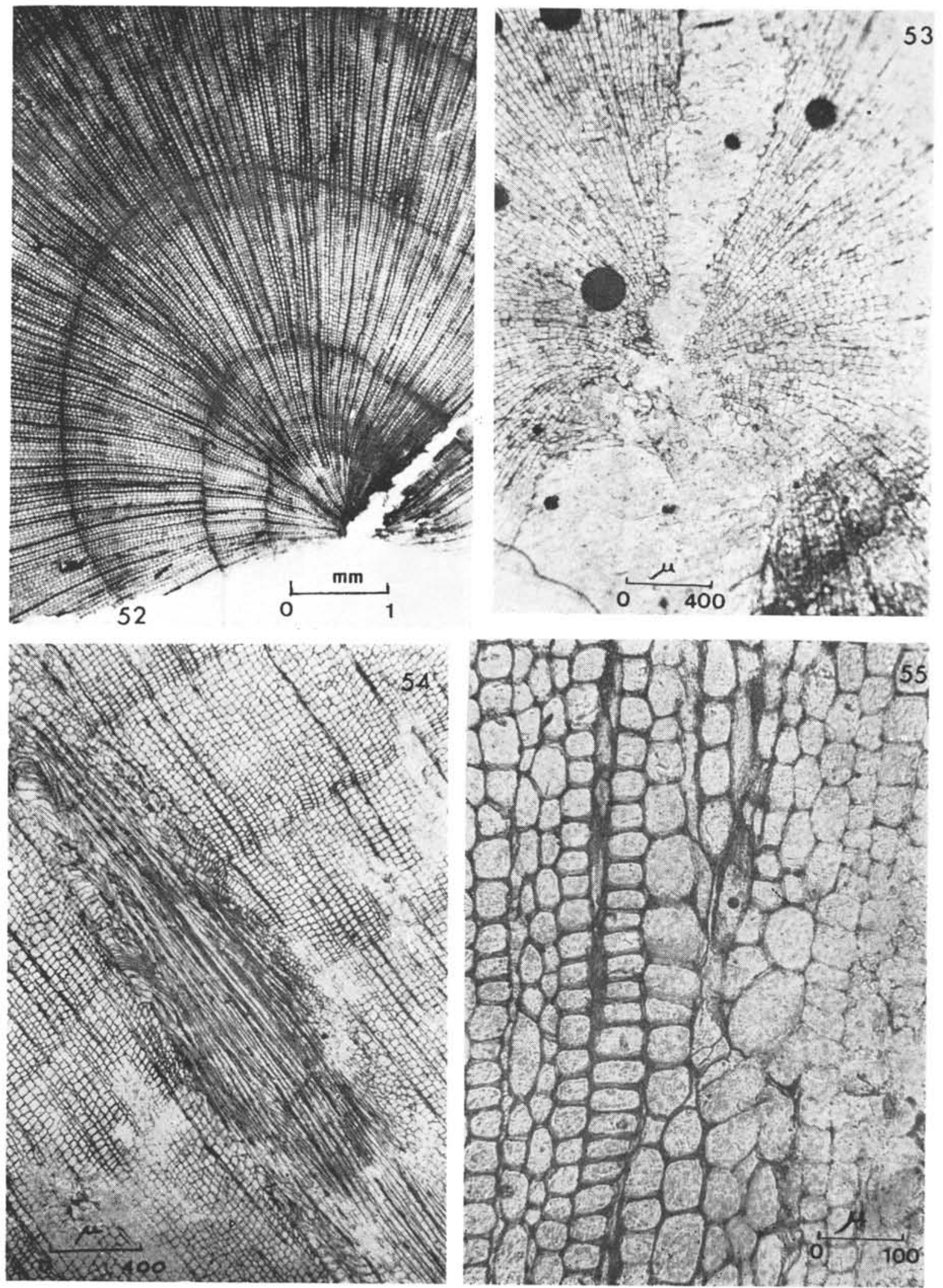


\section{PLATE $X$}

Paratordoxylon camposi ng., n. sp.

Fig. 56: Transversal section at level 5 (see Fig. 51) showing a new y formed stele which represent an adventitious branch in the major stele. 3,2 (GP/3T. 113).

Fig. 57: The same. Outer margin of the branch shown in Fig. 56. X 5. (GP/3T. 113).

Figs. 58-59:Longitudinal view of the pith in the minor adventitious branch; observe successively generated tracheidal platforms or girdles, similar to the reported platforms in the vertebrarian axis. $\times 25$. (GP/3T. 113).

Fig. 60: Pitting arrangement in the tracheids of late wood, showing the usual rosette groups of pits on the walls of the tracheids of late wood. $X 400$. (GP/3T. 1113). 


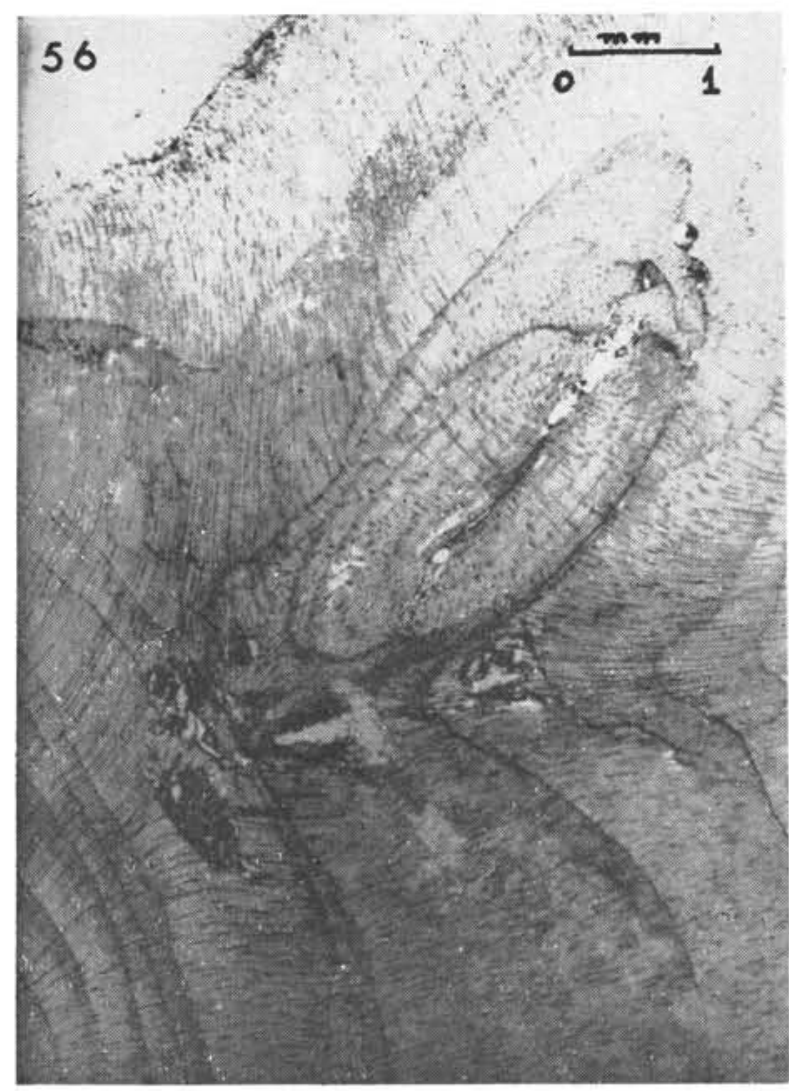

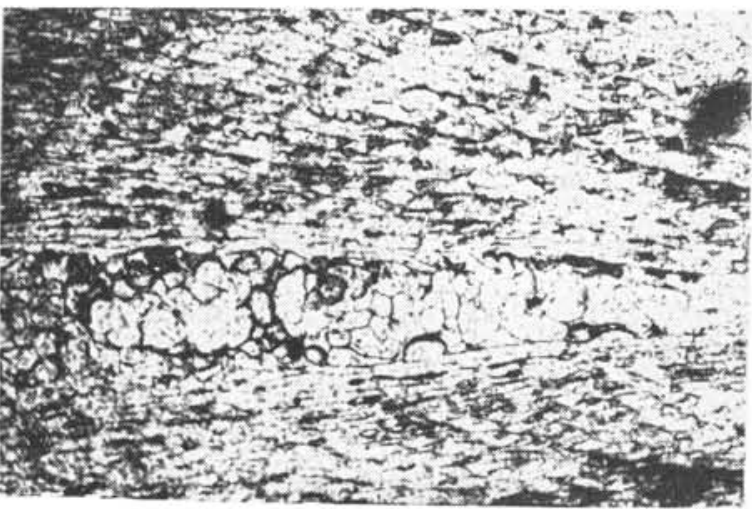

TSE

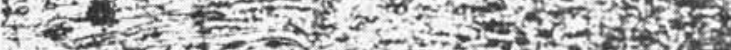

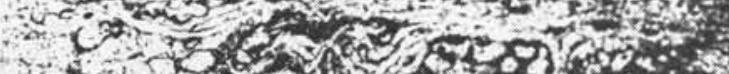

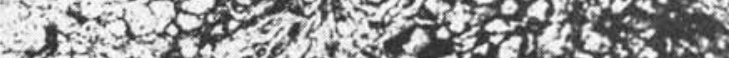

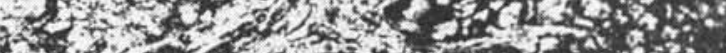

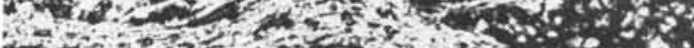

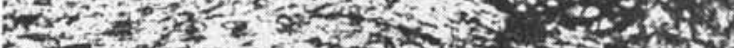

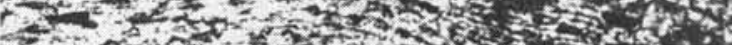

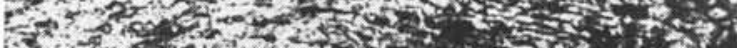

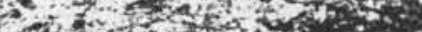

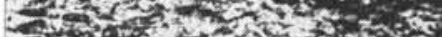

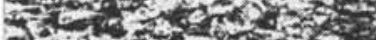

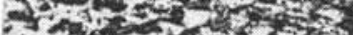

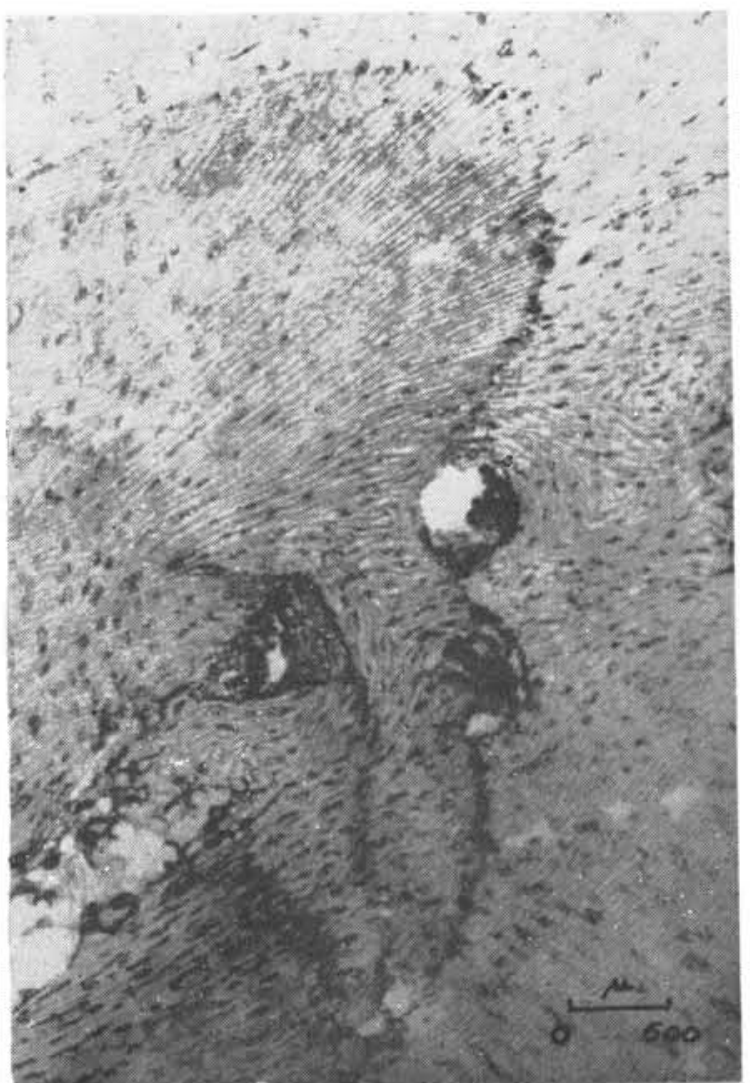

57

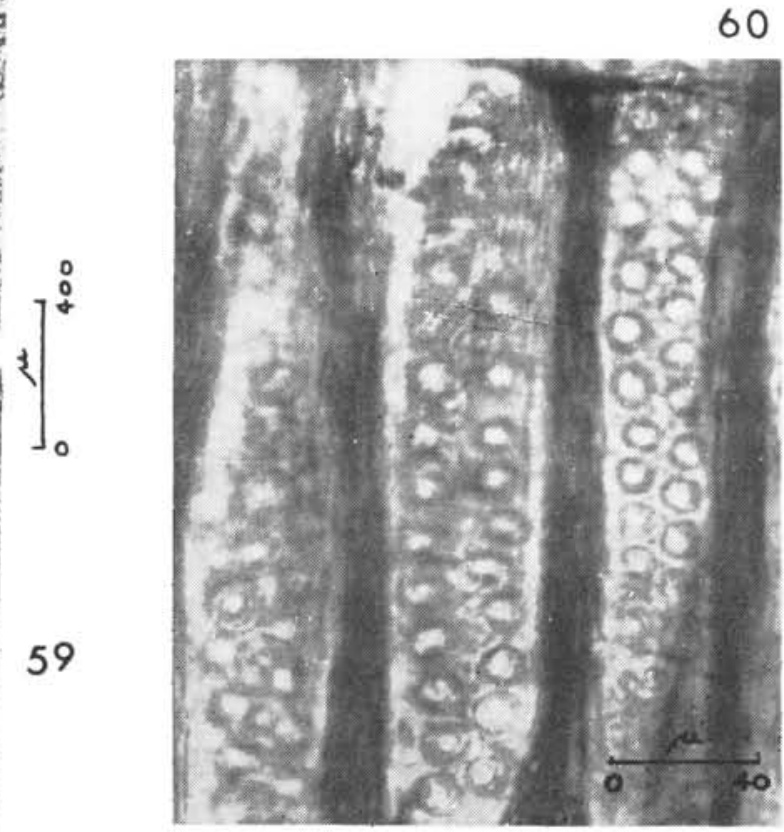




\section{PLATE XI}

Paratordoxylon camposi n. g., n. sp.

Figs. 61-63:Detail of a neo-formed xylem platform in the pith of the smaller stele with generating vascular elements from the pith parenchyma. $X 100$. (GP/3T. 113).

Fig. 62: Two whorls of vascular elements around the adventitious stele as connecting elements, between the major axis and the branch. $X 100$. (GP/3T. 1113).

Fig. 64: Sample GP/3T. 114: a curved branch in the calcareous matrix; thin closely spaced lines, as parallel furrows are seen in its external surface as in sample GP/3T. 113. 


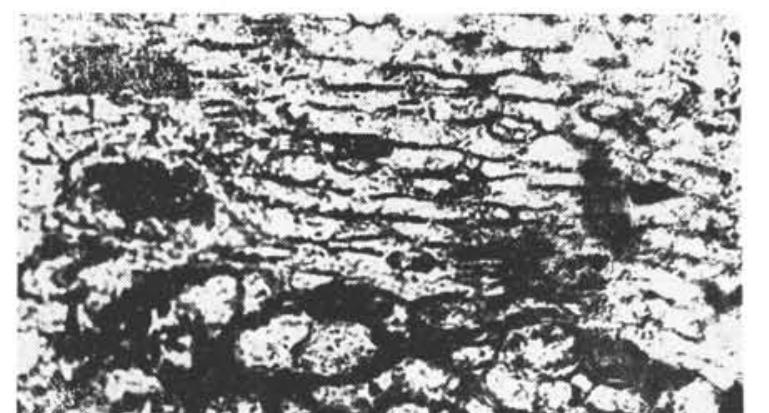

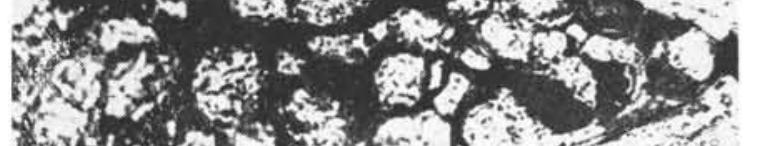

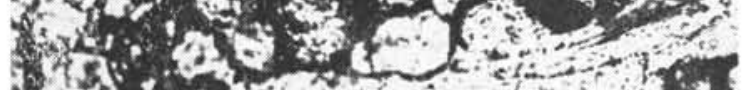
4. 0 e -

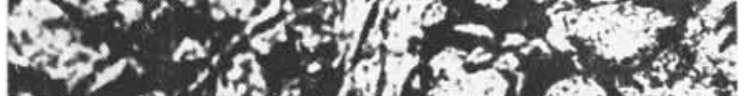

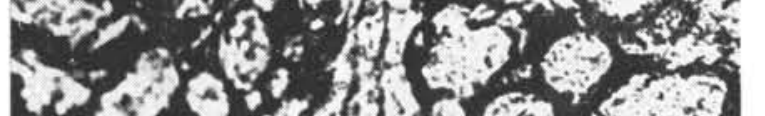

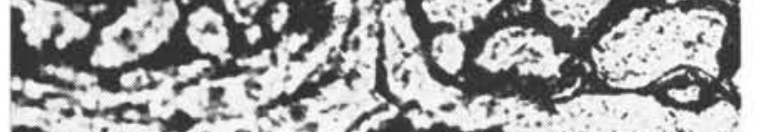

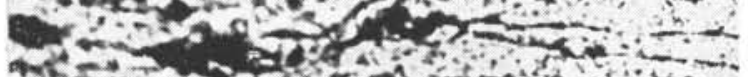

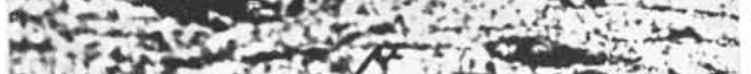

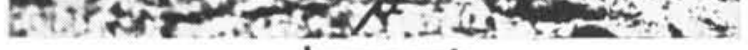

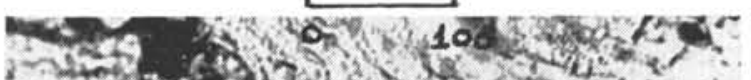

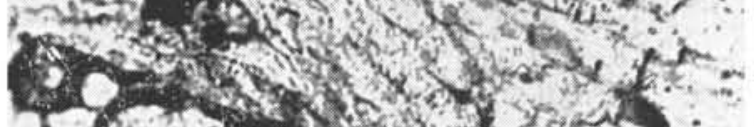

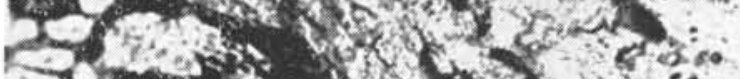

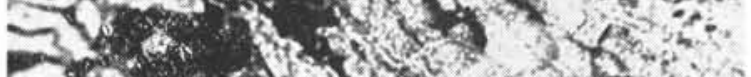
L Y 3 en

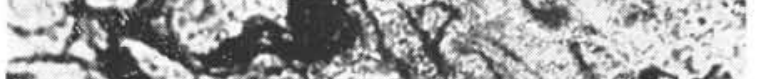

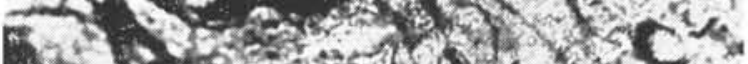

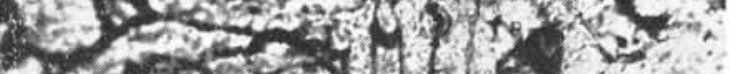

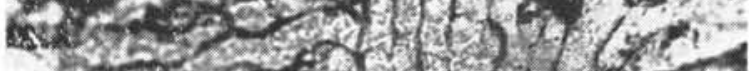

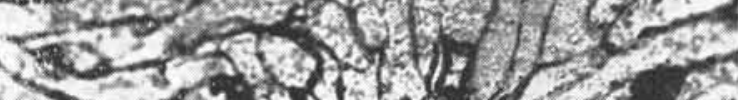

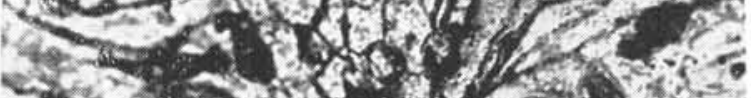

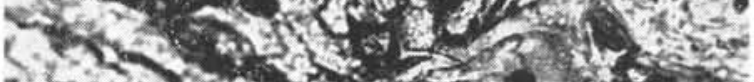

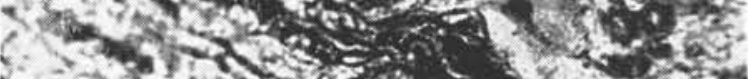

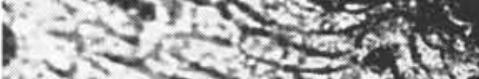

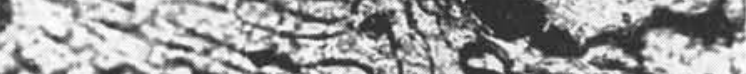

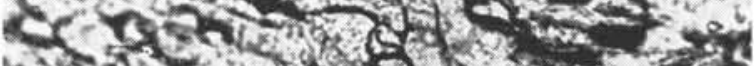

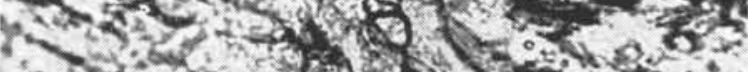

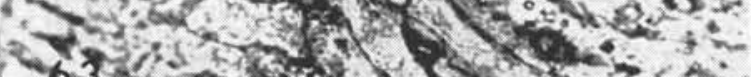
633 t 3 .

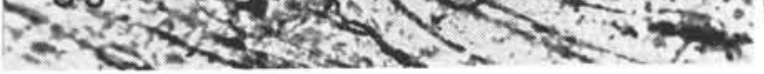
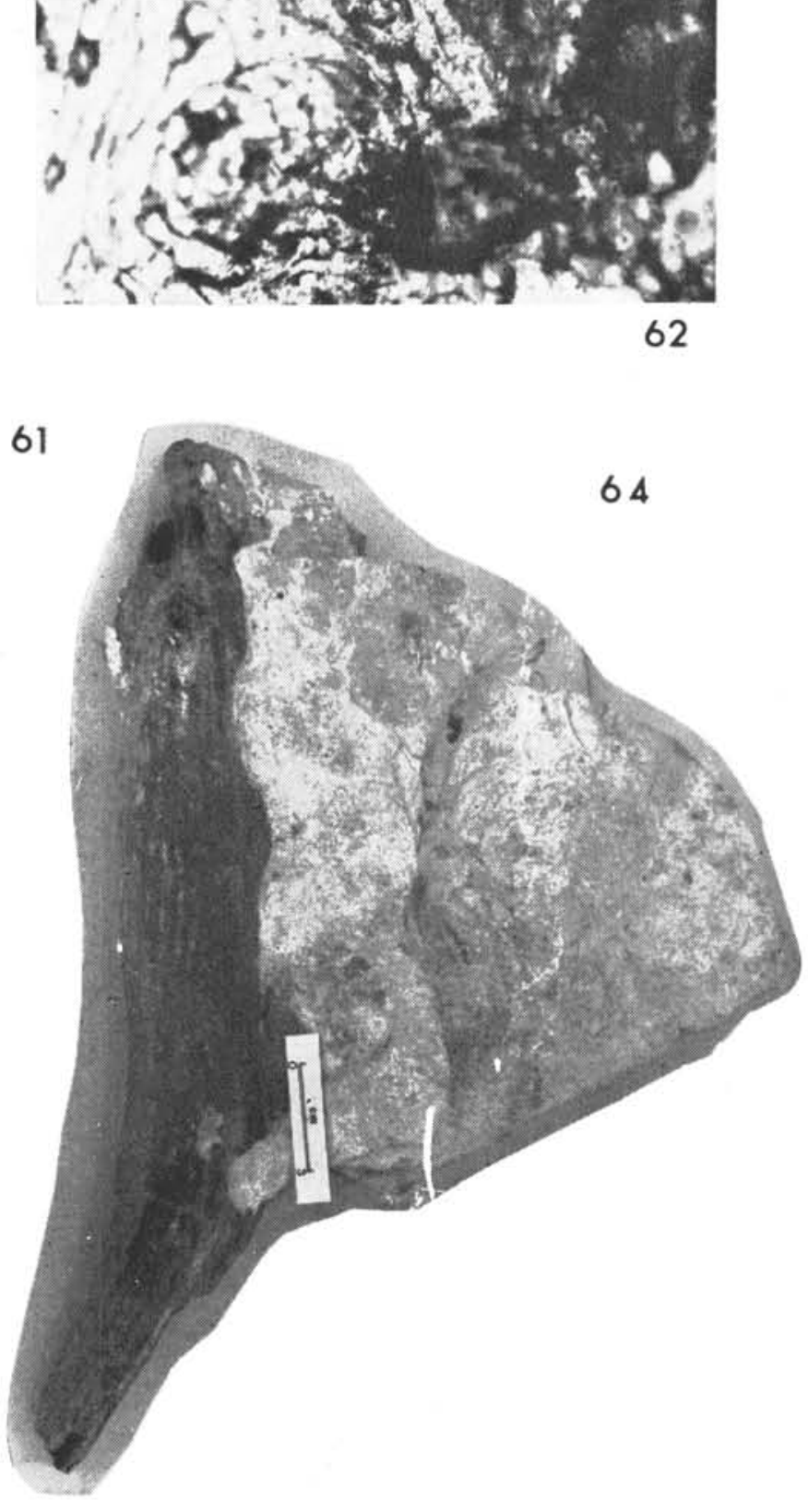